\title{
Human CCAAT-Binding Proteins Have Heterologous Subunits
}

Lewis A. Chodosh, $†$ Albert S. Baldwin,

Richard W. Carthew," $\neq$ and Phillip A. Sharp*

* Center for Cancer Research

and Department of Biology

Massachusetts Institute of Technology

Cambridge, Massachusetts 02139

† Harvard Medical School

Boston, Massachusetts 02115

\section{Summary}

We have characterized three distinct proteins present in HeLa cell extracts that specifically recognize different subsets of transcriptional elements containing the pentanucleotide sequence CCAAT. One of these CCAAT-binding proteins, CP1, binds with high affinity to CCAAT elements present in the human $\alpha$-globin promoter and the adenovirus major late promoter (MLP). A second protein, CP2, binds with high affinity to a CCAAT element present in the rat $\gamma$-fibrinogen promoter. Finally, the third CCAAT-binding protein is nuclear factor I (NF-I), a cellular DNA-binding protein that binds to the adenovirus origin of replication and is required for the initiation of adenoviral replication. CP1, CP2, and NF-I are distinct activities in that each binds to its own recognition site with an affinity that is at least three orders of magnitude higher than that with which it binds to the recognition sites of the other two proteins. Surprisingly, CP1, CP2, and NF-I each appear to recognize their binding site with highest affinity as a multisubunit complex composed of heterologous subunits. In the case of CP1, two different types of subunits form a stable complex in the absence of a DNA-binding site. Moreover, both subunits are present in the CP1-DNA complex. We thus propose the existence of a family of related multisubunit CCAAT-binding proteins that are composed of heterologous subunits.

\section{Introduction}

The central challenge in the study of eukaryotic gene expression is understanding how individual cells are able to stably maintain distinct levels and patterns of transcription from thousands of promoters. The rate of transcription initiation from promoters is specified by the interaction of sequence-specific DNA-binding proteins with cis-acting DNA control elements (reviewed in Maniatis et al., 1987). Thus, the activity of a promoter is determined both by its architecture, consisting of the type of control elements contained in the promoter and the context in which they appear, and by the requlatory state of the proteins that recognize these control elements. In view of this, a considerable degree of promoter diversity can be generated by

†Present address: Department of Biochemistry, University of California, Berkeley, California 94720 . the combinatorial use of a relatively small number of modular transcriptional elements.

Promoter diversity is further increased by the ability of related sets of control elements to be recognized by a family of proteins that possess distinct regulatory properties. A striking example of such a family is that of the nuclear hormone receptors. Nuclear hormone receptors are inducible trans-acting factors that stimulate transcription by binding to specific DNA control elements (reviewed in Yamamoto, 1985). Comparison of the cDNA clones encoding the glucocorticoid, estrogen, progesterone, triiodothyronine, mineralocorticuid, retinoic acid, and vitamin $D$ receptors has revealed conserved primary amino acid sequences in the DNA-binding domains of these receptors (Hollengerg et al., 1985; Weinberger et al., 1985; Green et al., 1986; Loosfelt et al., 1986; Weinberger et al., 1986; Arriza et al., 1987; Petkovich et al., 1987; McDonnell et al., 1987). Correspondingly, the control element sequences that these receptors specifically recognize are also conserved (Von der Ahe et al., 1986; Klock et al., 1987; Strahle et al., 1987). Thus, binding of a family of related transcription factors to a related set of control elements may result in a diverse set of regulatory consequences.

Many eukaryotic promoters possess a transcriptional regulatory element that contains the pentanucleotide sequence CCAAT between 60 and 80 bp upstream of the initiation site (Benoist et al., 1980; Efstratiadis et al., 1980; McKnight and Tjian, 1986). Several proteins that specifically recognize CCAAT elements have been described, however, the relationship between these proteins has been difficult to assess (Leegwater et al., 1985; Jones et al., 1985; Graves et al., 1986; Cohen et al., 1986; Hatamochi et al., 1986; Jones et al., 1987; Wu et al., 1987; Dorn et al., 1987; Barberis et al., 1987). Although these various CCAAT-containing elements appear grossly similar in sequence, recent evidence suggests that different DNAbinding factors are capable of distinguishing between these elements (Dorn et al., 1987; Oikarinen et al., 1987).

In this paper, we have characterized three related but distinct proteins from human cells which specifically recognize particular subsets of CCAAT elements. Surprisingly, all three of these CCAAT-binding proteins appear to be composed of at least two different subunits.

Results

MeLa Cell Proteins Specifically Bind to Three Different CCAAT Elements

The gel electrophoresis DNA-binding assay (Fried and Crothers, 1981; Garner and Revzin, 1981; Carthew et al., 1985) was used to detect proteins in HeLa cell extracts that specifically bind to CCAAT elements present in the adenovirus major late promoter (MLP), the rat $\gamma$-fibrinogen ( $\gamma$-FBG) promoter, and the consensus binding site sequence for NF-I (Figure 1). Each of the three probes containing a CCAAT element formed a specific protein-DNA 

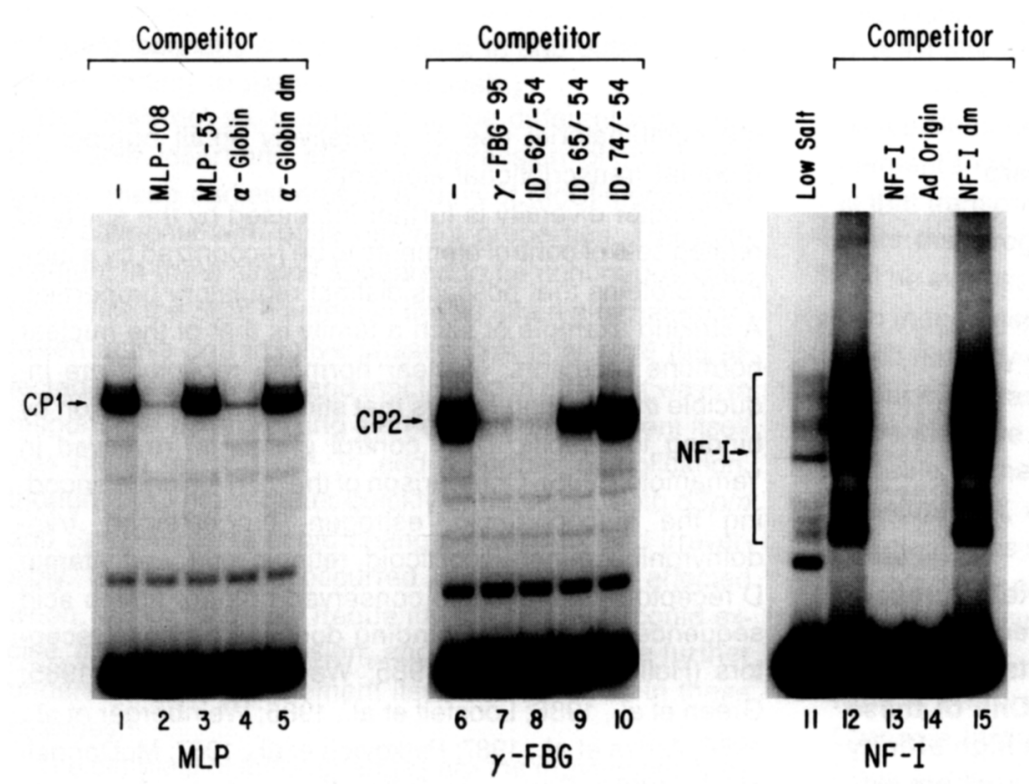

Figure 1. Specific Binding of HeLa Cell Proteins to Three CCAAT Elements

A mixture of $12 \mu \mathrm{g}$ of fraction $[A B]$ and $4 \mu \mathrm{g}$ of fraction $[\mathrm{CB}]$ was added to a standard binding reaction containing $2 \mu \mathrm{g}$ poly $(\mathrm{dl}-\mathrm{dC}) \cdot(\mathrm{dl}-\mathrm{dC})$, and $20,000 \mathrm{cpm}$ of either $0.1 \mathrm{ng}$ of a radiolabeled 74 bp MLP probe (lanes 1-5) containing $M L P$ sequences from -108 to -62 , including the MLP CCAAT element located at $-76,0.2 \mathrm{ng}$ of a radiolabeled 90 bp $\gamma$-FBG probe (lanes $6-10)$ containing sequences from -95 to -39 , including the $\gamma$-FBG CCACT element located at -65 , or 0.2 ng of a $77 \mathrm{bp}$ radiolabeled oligonucleotide probe containing the NF-I consensus binding site sequence (lanes 11-15), which contains sequences corresponding to +21 to +45 of the left terminus of $\mathrm{Ad} 2$ with a point mutation at +28 as described in Experimental Procedures. Reactions also contained either no additional DNA (lanes 1,6,11, and 12), or a 50 -fold molar excess of an unlabeled competitor DNA fragment (lanes 2-5, 7-10, and 13-15). Competitor fragments contained sequences from: -108 to -62 of the Ad MLP (lane 2); -53 to +33 of the Ad MLP (lane 3 ); -81 to -58 of

the human $\alpha$-globin promoter (lane 4 ); -81 to -58 of a mutant $\alpha$-globin promoter containing a double-point mutation in the CCAAT elernent (lane 5 ); -95 to -39 of the rat $\gamma$-FBG promoter (lane 7 ); -95 to +35 of the rat $\gamma$-FBG promoter with internal deletion of -62 to -54 (lane 8 ), -65 to -54 (lane 9), or -74 to -54 (lane 10); the NF-I consensus binding site (lane 13); the adenovirus origin of replication (lane 14); or a double-point mutant of the NF-l consensus binding site, NF-I-dm (lane 15). Radiolabeled probe, unlabeled competitor fragments, and poly(dl-dC) (dl-dC) were mixed prior to the addition of protein fractions [AB] and [CB]. Final reaction conditions were $60 \mathrm{mM} \mathrm{KCl,} 12 \% \mathrm{glycerol}, 12 \mathrm{mM} \mathrm{HEPES}-\mathrm{NaOH}$ ( $\mathrm{pH}$ 7.9), $4 \mathrm{mM}$ Tris- $\mathrm{HCl}(\mathrm{pH}$ 7.9), $1 \mathrm{mM}$ EDTA, and $1 \mathrm{mM}$ dithiothreitol for MLP binding reactions (lanes 1-5), for $\gamma$-FBG binding reactions (lanes $6-10$ ), and for the low salt NF-I binding reaction (lane 11). Final reaction conditions were $150 \mathrm{mM} \mathrm{KCl}, 5 \mathrm{mM} \mathrm{MgCl}, 12 \% \mathrm{glycerol}, 12 \mathrm{mM} \mathrm{HEPES}-\mathrm{NaOH}$ ( $\mathrm{pH} 7.9), 4 \mathrm{mM}$ Tris- $\mathrm{HCl}(\mathrm{pH} \mathrm{7.9),} 1 \mathrm{mM}$ EDTA, and $1 \mathrm{mM}$ dithiothreitol for the remaining NF-l binding reactions (lanes 12-15). Binding reactions, extract preparation, probe preparation, chromatography, and the gel electrophoresis DNA binding assay were as described in Experimental Procedures. Arrows indicate the position of specific protein-DNA complexes formed by CP1. CP2, and NF-l.

complex when mixed with partially purified chromatugraphic fractions from HeLa whole-cell extracts (WCE) (Figure 1, lanes 1, 6, and 12). An identical pattern of complexes was generated when unfractionated WCE was used (data not shown). A protein present in HeLa cell extracts, designated $C P 1$, specifically recognized sequences present between -108 and -62 bp relative to the MLP initiation site (Figure 1, lanes 1-3). A CCAAT pentanucleotide sequence is present in the MLP at -76 (Figure $2 B$ ). An oligonucleotide containing the human $\alpha$-ylobin CCAAT element competed efficiently for the binding of $C P 1$ to the MLP probe (Figure 1, lane 4). A double-point mutant in which the $\alpha$-globin CCAAT sequence was mutated to CGAGT (Figure 2B) failed to compete for $\mathrm{CP} 1$ binding to the MLP probe (Figure 1, lane 5). This suggests that CP1 recognizes sequences within the CCAAT pentanucleotide of the MLP.

Similarly, a protein present in HeLa cell extracts, designated CP2, specifically recognized sequences between -95 and -39 of the rat $\gamma$-FBG promoter (Figure 1, lanes 1 and 2). A CCAAT-related sequence, AGCCACT, is present in the $\gamma-F B G$ promoter at -65 (Figure $2 B$ ). An internal deletion mutant (ID-62/-54) of the promoter which retains only the sequence AGCCA competed efficiently for binding of CP2 to the wild-type $\gamma-\mathrm{FBG}$ probe (Figure 1, lane 8). Another mutant (ID-65/-54) with an internal deletion that is 3 bp larger (Figure $2 B$ ), and thus missing the CCA trinucleotide of the $\gamma$-FBG CCAAT-like element, com- peted poorly for CP2 binding (Figure 1, lane 9). This suggests that $\mathrm{CP} 2$ recognizes sequences within the CCAATlike element of the $\gamma-F B G$ promoter. A mutant (ID-74/-54) with a larger internal deletion encompassing the entire CCAAT-like element and additional upstream sequences was unable to compete for CP2 binding (Figure 1, lane 10). This indicates that CP2 makes additional important contacts upstream of the CCAAT-like element. A point mutant of the $\gamma$-FBG promoter that contained a canonical CCAAT pentanucleotide sequence competed for CP2 binding to the wild-type $\gamma$-FBG probe as efficiently as the wild-type promoter (data not shown). Thus, CP2 specifically recognizes CCAAT sequence elements.

In contrast to the MLP and $\gamma$-FBG promoter fragments, specific binding of HeLa cell proteins to an oligonucleotide probe containing the NF-I consensus binding site sequence, TTTGGCN ${ }_{5}$ GCCAAT (Leegwater et al., 1986; De Vries et al., 1987; Rosenfeld et al., 1987), was difficult to detect using the same reaction conditions that optimize the specific binding of CP1 and CP2 (Figure 1, lane 11). However, addition of $\mathrm{MgCl}_{2}$ to $5 \mathrm{mM}$ and $\mathrm{KCl}$ to $150 \mathrm{mM}$ resulted in a striking stimulation of specific binding activity to the NF-I probe (Figure 1, compare lanes 11 and 12). These conditions are known to increase NF-I binding activity (Rosenfeld and Kelly, 1986; Jones et al., 1987; De Vries et al., 1987). Moreover, the unusual pattern of protein-DNA complexes generated under these conditions was similar to that previously observed for affinity-purified 

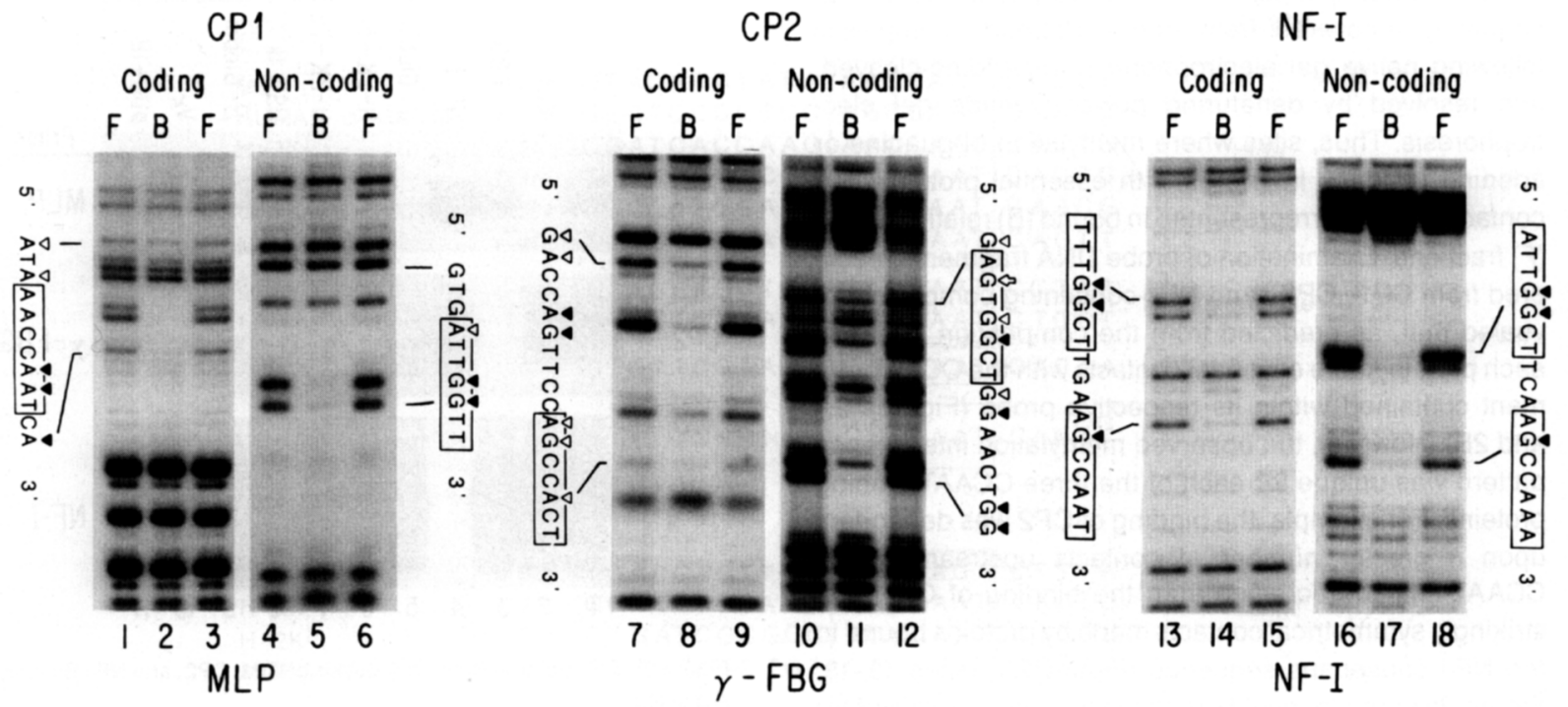

B

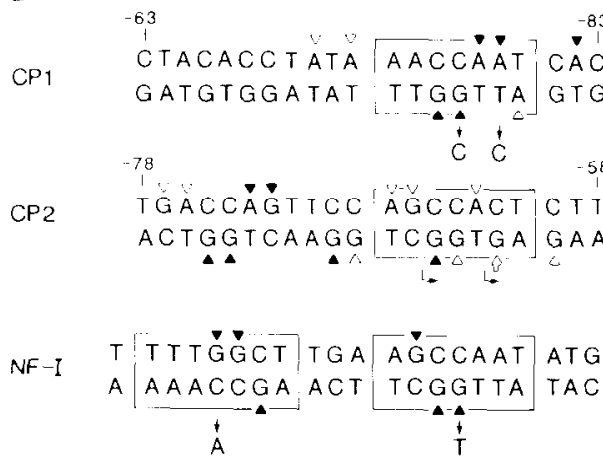

Figure 2. Methylation Interference Analysis of CP1. CP2. and NF. I Binding Activities

MLP (A) Methylation Interference Analysis. Methylation interference was performed as described in Experimental Procedures. $200.000 \mathrm{cpm}$ of a 3 end-labeled probe. containing either MLP sequences from - 108 to $-62, y$-FBG sequences from -95 to -39 , or the NF-I consensus binding site sequence was partially methylated with dimethylsulfate. puritied, and added to a scaled-up CP1, CP2, or NF-I binding reaction containing $10 \mu \mathrm{g}$ of poly(dl-dC) $(\mathrm{dl}-\mathrm{dC})$, and either no protein (lanes 1 . $3,4,6,7,9,10,12,13,15,16$, and 18 ), or a mixture of $130 \mu \mathrm{g}$ of fraction $[A B]$ and $58 \mu \mathrm{g}$ of [CB]. Bound, $(B)$, and free, $(F)$, probes were separated by native gel electrophoresis, visualized by autoradiography. eluted, purified, and cleaved with piperidine. An equal number of counts of free and bound DNA were electrophoresed on denaturing polyacrylamide gels. Coding and noncoding sequences are displayed along with a summary of the effects of partial methylation on the bind-

ing of CP1. CP2, and NF-I to their recognition sites. A box surrounds the heptanucleotide sequence corresponding either to the extended CCAAT consensus sequence. RRCCAAT. or its complement Residues at which methylation interfered with the binding of a protein to its recognition se. quence are indicated by triangles. Solid triangles represent a greater degree of interference than hoilow triangles. A residue at which methylation enhanced binding is indicated by a hollow arrow.

(B) Summary of Methylation Interference Analysis and Gel Clectrophoresis DNA-Binding Analysis. Cach of the three promoter sequences MLP. FBG, and the NF-1 consensus binding site sequence, recognized by CP1, CP2, and NF-I, respectively, are displayed along with a summary of the methylation interference analysis as performed in (A). Straight. solid arrows represent double-point mutations that abolish the binding of $C P 1$ and NF-I to their respective recognition sites as pertormed in Figure 1 . Bent arrows represent the $5^{\prime}$ internal deletion endpoints of iwo $\gamma^{-F B G}$ mutants that define essential contacts within the $\gamma$-FBG CCAAT element, as analyzed in Figure 1.

NF-I (Rosenfeld et al., 1987; Jones et al., 1987). As has been noted, this pattern probably reflects heterogeneity in the group of polypeptides forming these complexes since affinity-purified NF-I is similarly heterogeneous following SDS-polyacrylamide gel electrophoresis (Rosenfeld and Kelly, 1986; Jones et al., 1987). Binding to the NF-I consensus sequence probe was specifically competed by the homologous consensus sequence as well as by a DNA fragment containing the high-affinity NF-I binding site present in the adenovirus origin of replication (Figure 1, lanes 13 and 14; Nagata et al., 1983). Mutation of a single base in each GCCAA half site of the NF-I consensus sequence (Figure $2 \mathrm{~B}$ ) produced a sequence (NF-I-dm) that did not compete for the binding of NF-I polypeptides (Fig- ure 1, lane 15). Therefore, this entire set of proteins must make essential contacts with at least one CCAAT element in this probe. This double-point mutation has been shown to severely decrease NF-l binding affinity (Rosenfeld et al., 1987). Based upon the characteristic pattern of protein-DNA complexes formed on the NF-I probe, as well as the specific competition of these complexes by wild-type but not mutant sites, we conclude that the group of proteins in these complexes most likely corresponds to the previously identified NF-I.

In order to assess more closely the DNA contacts made by each of the CCAAT-binding proteins described above. a methylation interference experiment was performed (Siebenlist et al., 1980). DNA probes were partially methyl- 
ated by reaction with dimethylsulfate, and used as substrate in binding reactions. Probe fragments were subsequently recovered from free and bound complexes following native gel electrophoresis, piperidine-cleaved, and resolved by denaturing polyacrylamide gel electrophoresis. Thus, sites where methylation of guanine or adenine residues interferes with essential protein-DNA contacts are underrepresented in bound $(B)$ relative to free $(F)$ fractions. Examination of probe DNA fragments recovered from CP1-, CP2-, and NF-l-containing complexes revealed that, as predicted from the competition analysis, each protein made essential contacts with the CCAAT element contained within its respective probe (Figures $2 A$ and $2 \mathrm{~B}$ ). However, the observed methylation interference pattern was unique for each of the three CCAAT-binding proteins. For example, the binding of $\mathrm{CP} 2$ was dependent upon a greater number of contacts upstream of the CCAAT-related sequence than the binding of CP1. The strikingly symmetrical contacts made by proteins bound to the NF-I consensus sequence (Figure 2A, lanes 13-18; Figure $2 B$ ) are identical to those previously described for the binding of purified NF-I (De Vries et al., 1987).

In summary, the methylation interference analysis confirms that $\mathrm{CP} 1, \mathrm{CP} 2$, and NF-I are CCAAT-binding proteins in that each protein makes essential contacts within the CCAAT pentanucleotide. In addition, variation in the patterns of methylation interference, as well as differences in the mobility of the protein-DNA complexes, suggest that $\mathrm{CP} 1, \mathrm{CP} 2$, and NF-I are distinct proteins.

\section{CP1, CP2, and NF-I Are Distinct CCAAT-Binding Proteins}

In order to examine the relationship between the specificities of proteins binding to CCAAT elements in a variety of promoters, a competition analysis was performed in which a radiolabeled probe was incubated in the presence of a 100-fold molar excess of an unlabeled DNA fragment. Each of the CCAAT elements examined has been shown to contribute to the transcriptional activation of the promoter from which it is derived, except for the $V_{k}$ CCAAT element ( $L$. Chodosh and $R$. Carthew, unpublished results; Morgan et al., 1988; Chodosh et al., 1987; Miksicek et al., 1987; Mellon et al., 1981; A. Baldwin, unpublished results; Jones et al., 1985; Graves et al., 1986; Charnay et al., 1985; Myers et al., 1986). The results of these competition experiments are shown in Figure 3 , in which panels representing the bound complexes generated on three different probes are mounted beneath each other. Thus, the ability of a particular DNA fragment to compete for complexes formed on each of the three probes can be directly compared. The MLP fragment competed for the binding of CP1 to the MLP probe, and had no effect upon the binding of CP2 to the $\gamma-F B G$ probe or upon the binding of NF-I to the NF-I consensus sequence probe (Figure 3, lanes 1 and 2). Similarly, the $\gamma$-FBG promoter fragment competed for the binding of $\mathrm{CP} 2$ to the homologous probe, and had no effect upon the binding of CP1 to the MLP probe or upon the binding of NF-I to the NF-I consensus sequence probe (Figure 3, lane 3). Finally, the NF-I consensus sequence fragment competed for the binding

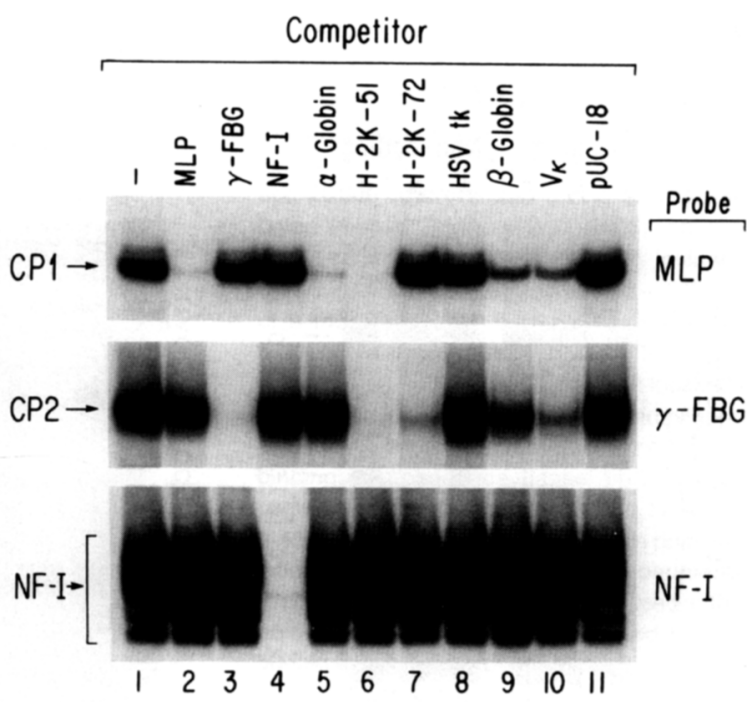

Figure 3. Competition Binding Analysis of $\mathrm{CP} 1, \mathrm{CP} 2$, and NF-I Binding Activities

A mixture of $12 \mu \mathrm{g}$ of $\mathrm{HeLa}$ fraction [AB] and $4 \mu \mathrm{g}$ of HeLa fraction [CB] (lanes 1-11) was added to a standard binding reaction for either CP1 (top panel), CP2 (middle panel), or NF-I (bottom panel) containing a mixture of the indicated probe, $2 \mu \mathrm{g}$ poly $(\mathrm{dl}-\mathrm{dC}) \cdot(\mathrm{dl}-\mathrm{dC})$, and either no competitor DNA (lane 1) or a 100-fold molar excess of an unlabeled competitor DNA fragment (lanes 2-11). Competitor fragments contained sequences from: -108 to -62 of the Ad MLP (lane 2); -95 to -39 of the rat $\gamma-F B G$ promoter (lane 3 ); the consensus binding site of NF.I, corresponding to +21 to +45 of the left terminus of $\mathrm{Ad} 2$ with a point mutation at +28 (lane 4 ): -81 to -58 of the human $\alpha$-globin promoter (lane 5 ); -65 to +3 of the mouse $\mathrm{H}-2 \mathrm{~K}^{\mathrm{b}}$ promoter (lane 6 ); -90 to -64 of the mouse $\mathrm{H}-2 \mathrm{~K}^{b}$ promoter (lane 7 ); -94 to -70 of the HSV thymidine kinase promoter (lane 8 ); -344 to -15 of the mouse $\beta$-globin promoter (lane 9 ); -297 to -47 of the MOPC $-41 V_{k}$ promoter (lane 10 ); or the 50 bp polylinker of pUC18 (lane 11). Binding reactions were analyzed by native gel electrophoresis as above. Following autoradiography, panels corresponding to the bound complexes formed on each of the three probes were excised and mounted together for direct comparison. Arrows indicate the position of specific protein-DNA complexes formed by CP1, CP2, and NF-1.

of NF-I to the consensus sequence probe, and had no effect upon the binding of CP1 to the MLP probe or upon the binding of CP2 to the $\gamma$-FBG probe (Figure 3, lane 4). This suggests that CP1, CP2, and NF-I are distinct CCAATbinding proteins with dramatically different affinities for these three binding sites.

In support of the conclusion that CP1, CP2, and NF-I possess distinct binding specificities, each CCAAT-binding protein displayed a characteristic pattern of binding of a panel of unlabeled competitor fragments containing different CCAAT elements (Figure 3; Table 1). For example, $C P 1$ bound with high affinity to fragments containing the MLP, the human $a$-globin CCAAT element, and the mouse class I major histocompatibility gene $\mathrm{H}-2 \mathrm{~K}^{\mathrm{b}}-51 \mathrm{CCAAT}$ element, and with somewhat lower affinity to fragments containing the murine $\beta$-globin promoter and the MOPC-41 $\mathrm{V}_{\mathrm{h}}$ promoter (Figure 3, lanes 2, 5, 6, 9, and 10). CP1 also bound with high affinity to the murine sarcoma virus (MSV) LTR and the human heat shock protein 70 (hsp70) promoter, and with low affinity to the herpes 
Table 1. Sequence Comparison of CP1, CP2 and NF.I Binding Sites

\begin{tabular}{|c|c|c|c|c|c|}
\hline \multicolumn{5}{|l|}{ CP1 } & Affinity \\
\hline ML.P & $(-76)$ & $C T A C A C C T A T A$ & AACCAAT & $C A C C T$ & \multirow{6}{*}{ High } \\
\hline HUMAN $a$-GLOBIN & $(-70)$ & GGCTCCGCGCC & AGCCAAT & GAGCG & \\
\hline $\mathrm{H}-2 \mathrm{~Kb}$ & $(-51)$ & CGATCACCAAG & AACCAAT & $C A G T G$ & \\
\hline $\mathrm{HSP} 70^{\prime}$ & $(-70)$ & $T T T C C C T T C T G$ & AGCCAAT & $C A C C G$ & \\
\hline UAS2UP1-CYC1 & $(-204)$ & ACCGCT TGATC & CACCAAT & $C A A C G$ & \\
\hline MSV LTR & $(-81)$ & TTATTTGAACT & AACCAAT & CAGT T & \\
\hline$M O P C-41 V_{k}$ & $(-89)$ & ACAGCAGCTGT & $\overline{G A C C A A T}$ & CCTAA & \multirow{2}{*}{ Moderate } \\
\hline MOUSE $\beta$-GLLUBIN & $(77)$ & ACTCTGGTAAG & GGCCAAT & $\mathrm{C} T \mathrm{G} C \mathrm{~T}$ & \\
\hline HSV tk & $(-82)$ & GTGTTCGAATT & $\mathrm{CGCCAAT}$ & GACAA & Low \\
\hline CP1 Consensus & & ${ }_{T}^{C} N N N N N N$ & $\begin{array}{l}A A C C A A T \\
G G\end{array}$ & $C A N \underset{T}{C G}$ & \\
\hline \multicolumn{6}{|l|}{$\underline{\mathrm{CP} 2}$} \\
\hline $\mathrm{FBG}$ & $|-65|$ & TGACCAGTTCC & $A G C L A C T$ & C I TTA & \multirow{4}{*}{ High } \\
\hline $\mathrm{H}-2 \mathrm{~Kb}$ & $|-51|$ & $C G A T C A C C A A G$ & $A A C C A A T$ & CAGTG & \\
\hline$H-2 K b$ & $(-72)$ & GTGATCGCGCC & ACCCAAT & GGGGG & \\
\hline MOPC $-41 V_{K}$ & $(-89)$ & CT TGCAGCTGT & GACCAAT & $C C T A A$ & \\
\hline MOUSE $\beta$-GLOBIN & $|-77|$ & $A C C C T G G T A A G[$ & GGCCAAT & $C T G C T$ & Moderate \\
\hline $\mathrm{CP}_{2}$ Consensus & & ${ }_{\mathrm{T}}^{\mathrm{C}} \mathrm{AG} \underset{\mathrm{T}}{\mathrm{C}} \mathrm{NNN}$ & $\mathrm{G}_{\mathrm{G}} \mathrm{RCCA} A \mathrm{~T}$ & CNNNR & \\
\hline \multicolumn{6}{|l|}{$N F-I$} \\
\hline$N F-I$ & & $T / T$ T T G G T T G A & AGCCAAT & ATGAG & \multirow{3}{*}{ High } \\
\hline Ad ORIGIN & & $T$ T T T GGATT G A & $A G C C A A T$ & ATGAG & \\
\hline NF-I Consensus ${ }^{2}$ & & NTTGGCNNNN & NGCCAAN & & \\
\hline
\end{tabular}

The sequences of a number of CCAAT elements referred to in the text were aligned according to the best fit to the boxed CCAAT-eleriterit inulif RRCCAAT, and grouped by relative affinity for CP1, CP2. and NF-I, as measured by the gel electrophoresis DNA-binding assay. High. moderate and low affinities differ by a factor of at least five. The number listed immediately to the left of each sequence indicates the position of the most extreme $\mathrm{C}$ of the CCAAT pentanucleotide relative to the transcription initiation site. A consensus binding site sequence is presented for each of the three CCAAT-binding proteins. The consensus binding site sequences for CP1 and CP2 were derived from an affinity-weighted analysis of each of the binding sites listed. Consensus sequence positions which have one nucleotide listed above another (e.g. A) indicate a preference for the nucleotide listed on top. $R$ indicates a similar preference for $A$ or $G$.

$1 \mathrm{M}$. Pelletier and $\mathrm{R}$. Kingston, personal communication and $\mathrm{L}$. Chodosh, data not shown.

2 The NF-I consensus binding site sequence is derived from Rosenfeld et al. (1987) and De Vries et al. (1987)

simplex virus thymidine kinase (HSV $\mathrm{tk}$ ) CCAAT element (data not shown; Figure 3, lane 8; M. Pelletier and R. Kingston, personal communication). Like CP1. CP2 recognized a fragment containing the $\mathrm{H}-2 \mathrm{~K}^{\mathrm{b}}-51 \mathrm{CCAAT}$ element with high affinity (Figure 3, lane 6). Unlike $\mathrm{CP} 1, \mathrm{CP} 2$ also recognized fragments containing the $\mathrm{H}-2 \mathrm{~K}^{\mathrm{b}}-72$ CCAAT element with high affinity, and did not bind to a tragment containıng the $\alpha$-globin CCAAT element (Figure 3, lanes 5 and 7). In marked contrast to both $\mathrm{CP} 1$ and $\mathrm{CP} 2$, NF-I did not bind to any other CCAAT-containing fragment tested (Figure 3, lanes 2-11). In particular, the a-globin promoter failed to even partially compete at a 100-fold molar excess with any complex characteristic of NF-I binding (Figure 3, lane 5). Thus, the group of proteins which we have characterized as NF-1 recognize the $\alpha$-globin CCAAT element with an affinity that is at least three orders of magnitude lower than the affinity with which they recognize the NF-I consensus binding site. This was surprising since NF-I had previously been reported to bind to the $\alpha$-globin
CCAAT element with an affinity that was only five times lower than that with which NF-I bound to the adenovirus origin of replication (Jones et al., 1987). In order to test for weak binding to the $\alpha$-globin promoter by NF-I, a probe containing the $a$-globin CCAAT element was radiolabeled and used as substrate in a binding reaction under conditions optimal for NF-I binding. Complexes characteristic of NF-I binding, either by electrophoretic mobility or specific competition, were not detected. Complexes characteristic of NF-I binding were also not detected under the low salt conditions optimal for CP1 binding to the $\alpha$-globin promoter (data not shown)

Competition analysis using extremely high molar ratios of competitor to probe demonstrated that each of the three CCAAT-binding proteins recognized binding sites for the other two proteins with a higher affinity than that with which it recognized non-CCAAT-element containing control fragments of comparable length (data not shown). This was not unexpected, since the core scquences of 
each of these CCAAT-containing elements are quite similar. The distinct binding specificities of the three CCAATbinding proteins must therefore reflect contacts outside of the CCAAT pentanucleotide sequence. Comparison of the methylation interference contacts of CP1, CP2, and NF-1, as well as the consensus binding site sequences for each of these three proteins, supports this conclusion (Figures $2 \mathrm{~A}$ and 2B; Table 1). High-affinity $\mathrm{CP} 1$ binding shows a strong preference for a CA dinucleotide immediately 3 ' to the CCAAT pentanucleotide. In contrast, high-affinity CP2 binding shows a strong preference for sequences $b$ ' to the CCAAT pentanucleotide. Interestingly, despite their differences, the consensus binding site sequences of $\mathrm{CP} 1$ and CP2 do share similarities at several positions outside of the CCAAT pentanucleotide sequence. Unlike both CP1 and CP2, NF-I clearly binds with high affinity to two symmetrically disposed CCAAT elements.

The competition binding patterns of CP1, CP2, and NF-1 revealed examples of CCAAT elements that bound only one of the three proteins with high affinity (MLP, $\gamma$-FBG, NF-I, $\alpha$-globin, $\mathrm{H}-2 K^{b}-72$ ), as well as examples of CCAAT elements that bound two CCAAT proteins with moderate to high affinity $\left(\mathrm{H}-2 \mathrm{~K}^{b}-51, \mathrm{MOPC}-41 \mathrm{~V}_{k}, \beta\right.$-globin). The HSV tk promoter bound CP1 with low affinity, and did not detectably bind to either CP2 or NF-I. Analysis of the binding of HeLa cell proteins to a labeled fragment containing the HSV tk CCAAT element confirmed the specific binding of $\mathrm{CP} 1$, and also revealed the presence of an additional rapidly migrating specific complex of comparable abundance to that formed by CP1. Generation of this complex may be due to the previously described CCAAT-binding protein, CBP (data not shown). The $\mathrm{H}-2 \mathrm{~K}^{b}$ promoter presented an interesting example in which one CCAAT element $(-51)$ bound both CP1 and CP2 with high affinity, while an adjacent CCAAT element (-72) selectively bound only CP2 with high affinity (Figure 3 , lanes 6 and 7). Deletion of sequences containing either one of these CCAAT elements resulted in a 10 -fold reduction in transcription in vivo (A. Baldwin, unpublished results). However, on the basis of this data alone, it is unclear whether the loss of transcription activity resulted from the loss of binding of a particular CCAAT-binding factor.

The binding specificities of CP1, CP2, and NF-I were reproducibly observed in multiple nuclear extracts prepared from HeLa cells. The same three binding specificities were observed in HeLa whole-cell extracts. Thus the binding specificities defining $\mathrm{CP} 1, \mathrm{CP} 2$, and NF-I are not dependent upon the method of extract preparation. It seems highly unlikely that these three binding specificities result from the in vitro modification of a single progenitor protein. Such a modification would have to occur rapidly and precisely in multiple extracts to alter extensively the binding specificity of the protein. Protein modifications of this kind have not been described previously.

\section{Optimal Binding of CP1, CP2, and NF-1 Requires Two Chromatographic Fractions}

Since HeLa cell extracts had been shown to contain at least three distinct CCAAT-binding proteins by the above analysis, we wished to determine if these activities could be separated chromatographically. Surprisingly, resolution of HeLa whole cell extracts into four fractions by phos phocellulose chromatography resulted in an almost complete loss of binding activity for each of the three CCAATbinding proteins (data not shown). Pair-wise combination of the four phosphocellulose fractions revealed that addition of the $0.04 \mathrm{M} \mathrm{KCl}$ flowthrough fraction $A$ to the $0.6 \mathrm{M}$ fraction $C$ resulted in a striking restoration of binding activity for each of the three CCAAT-binding proteins (data not shown). A similar result was observed following chromatography of a murine erythroleukemia cell extract on heparin-agarose (data not shown). For each of the CCAATbinding proteins, the activities present in fraction $A$ and in fraction $C$ were followed through an additional chromatographic step. The activity present in fraction $A$ bound to a DEAE column and was eluted by a 0.15 to $0.35 \mathrm{M} \mathrm{KCl}$ step (fraction $A B$; see Experimental Procedures). Similarly, the activity present in fraction $C$ bound to a singlestranded DNA cellulose column and was eluted by a 0.1 to $0.3 \mathrm{M} \mathrm{KCl}$ step (fraction $\mathrm{CB}$; see Experimental Procedures). Although neither fraction $A B$ nor fraction $C B$ exhibited significant specific DNA-binding activity alone, combination of $A B$ and $C B$ resulted in a dramatic increase in the specific binding activity of CP1, CP2, and NF-I (Figure $4 A$, lanes $1-3,7-9$, and 13-15). Combining fractions $A B$ and $C B$ resulted in a $30-$ to 50 -fold stimulation of $C P 1$ binding activity, and in a 5- to 10-fold stimulation of CP2 and NF-I binding activities. No other combination of chromatographic fractions resulted in a significant stimulation of binding (data not shown). Trypsin treatment demonstrated that the active component in each fraction was a protein (data not shown). Binding was not stimulated by the addition of unrelated proteins such as bovine serum albumin to either fraction (data not shown). Thus, fraction $A B$ contained binding activities CP1A, CP2A, and NF-IA. Similarly, fraction $\mathrm{CB}$ contained binding activities $\mathrm{CP} 1 \mathrm{~B}$, CP2B, and NF-IB.

\section{CP1, CP2, and NF-I Do Not Share Common Subunit Binding Activities}

The surprisingly similar chromatographic behavior of the subunit activities of $\mathrm{CP} 1, \mathrm{CP} 2$, and NF-I raised the possibility that the three CCAAT-binding proteins might have common subunits. This possibility was examined by eluting CP1A, CP2A, and NF-IA activities from a DEAE column, and CP1B, CP2B, and NF-IB activities from a single-stranded DNA-cellulose column, with linear salt gradients. This provides better resolution than the discontinuous steps used to generate the original fractions $A B$ and $\mathrm{CB}$. Chromatography of phosphocellulose fraction $C$ on single-stranded DNA-cellulose resulted in the clear separation of each of the three component activities (Figure 4A). CP1B activity eluted primarily in fraction $8, C P 2 B$ activity eluted almost exclusively in fraction 10, and NF-IB activity eluted primarily in fraction 12 (Figure $4 A$, lanes 4 , 11, and 18). Therefore, CP1B, CP2B, and NF-IB each have distinct chromatographic behavior. Similarly, chromatography of phosphocellulose fraction $A$ on DEAE-Sephacel revealed that while $C P 1 A$ activity peaked in fraction 80 , CP2A exhibited a broad elution profile peaking in fraction 
A
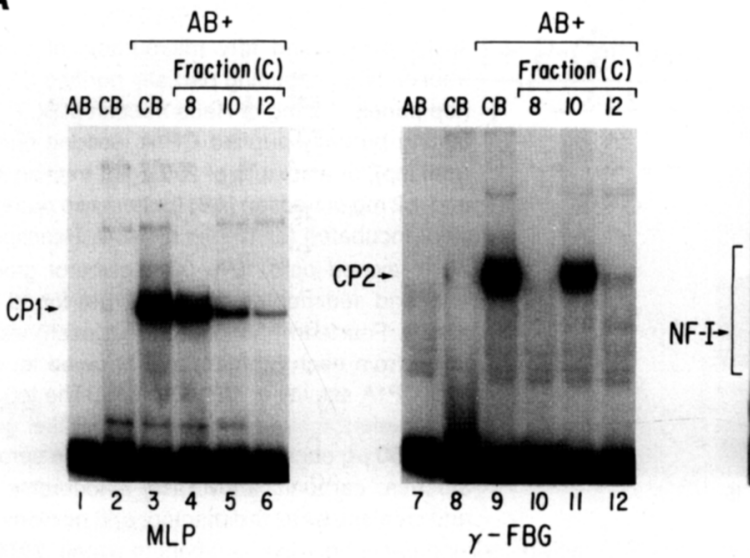

Figure 4. Optimal Binding of $\mathrm{CP} 1, \mathrm{CP} 2$, and NF-I Requires Two Chromatographic Fractions (A) Chromatography of CP1B, CP2B, and NF. IB. $20,000 \mathrm{cpm}$ of a radiolabeled probe containing sequences from either the Ad MLP (lanes 1-6), the $\gamma$-FBG promoter (lanes 7-12), or the NF-I consensus binding site (lanes 13-18), was added to a standard binding reaction containing either $12 \mu \mathrm{g}$ of fraction [AD] alone (lanes 1. 7 , and 13), $4 \mu \mathrm{g}$ of fraction [CB] alone (lanes 2. 8 , and 14 ), or a mixture of $12 \mu \mathrm{g}$ of fraction [AB] (lanes 3-6, 9-12, and 15-18) and either 4 !Ig of fraction [CB] (lanes 3, 9, and 15), or $4 \mu \mathrm{g}$ of DNA-cellulose gradient fraction 8 (lanes 4, 10 . and 16), fraction 10 (lanes 5,11 , and 17), or fraction 12 (lanes 6,12 , and 18). Binding reactions were performed and analyzed by native gel electrophoresis as above. Chromatography of HeLa fraction [C] over DNA-cellulose was performed as in Experimental Procedures. Arrows indicate specific protein-DNA complexes formed by CP1, CP2, and NF-I

B

$\mathrm{CB}+$

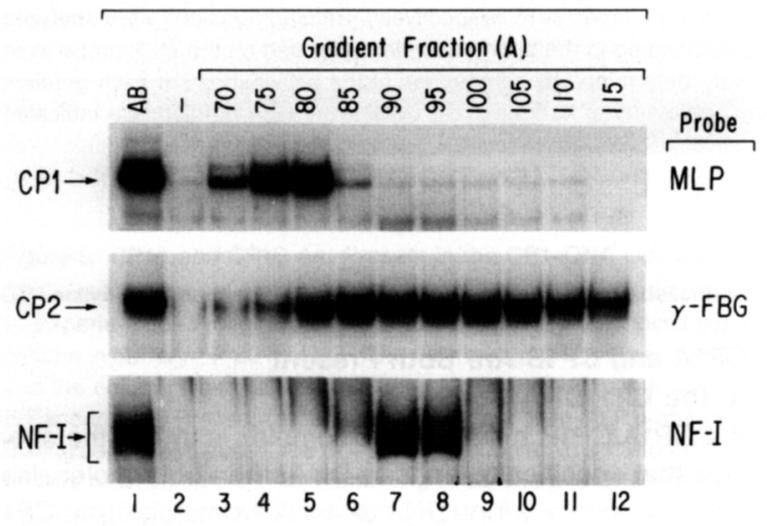

(B) Chromatography of CP1A, CP2A, and NFIA. $20,000 \mathrm{cpm}$ of a radiolabeled probe containing sequences from either the Ad MLP (top panel), the $\gamma$-FBG promoter (middle panel), or the NF-I consensus sequence (bottom panel) was added to a standard binding reaction containing $4 \mu \mathrm{g}$ of HeLa fraction [CB] (lanes 1-12). and either $12 \mu \mathrm{g}$ of HeLa fraction [AB] (lane 1) $1 \mu$ of chromatography butter (lane 2), or $1 \mu$ l of the indicated chromatographic gradient fraction derived from fractionation of HeLa fraction [A] over DEAE-Sephacel as in Experimental Procedures (lanes $3-12$ ). Binding reactions were analyzed by native gel electrophoresis as above. Following autoradiography, panels corresponding to the bound complexes formed on each of the three probes were excised and mounted together for direct comparison. Arrows indicate the position of specific protein-DNA complexes formed by CP1, CP2, and NF-I.

85, and NF-IA activity peaked in fraction 90 (Figure 4B, lanes 5-7). Clearly, CP1A activity chromatographs in a distinct fashion from CP2A and NF-IA. The relationship between the chromatographic behavior of CP2A and NF-IA activities, however, is less clear. The observation that CP2A and NF-IA activities peak in separate fractions, and that the CP2A activity peak is quite broad while the NF-IA peak is relatively narrow, suggests that CP2A and NF-IA activities are distinct. This hypothesis is further supported by competition experiments performed in the presence of limiting amounts of fraction $\mathrm{AB}$ (data not shown). Under these conditions, a 100-fold molar excess of an unlabeled $\gamma$-FBG promoter fragment failed to compete for NF-I binding. Similarly, the NF-I consensus binding site fragment failed to compete for CP2 binding.

\section{CP1A and CP1B Form a Stable Complex in the Absence of a DNA-Binding Site}

The observation that maximum binding activity of each of three CCAAT factors required the addition of two chromatographic fractions suggested that at least two distinct subunits might be present in the CCAAT factor-DNA com- plex. Thus, if these subunits form a stable complex in HeLa cell extracts, but are separated by cation-exchange chromatography, a binding activity present in unfractionated extracts would appear absent in chromatographic fractions. When the appropriate fractions containing the two subunits were combined, they could reassociate and thereby regenerate the original binding activity. In order to test this possibility, partially purified fractions containing $\mathrm{CP} 1 \mathrm{~A}$ alone, $\mathrm{CP} 1 \mathrm{~B}$ alone, or a combination of $\mathrm{CP} 1 \mathrm{~A}$ and $\mathrm{CP} 1 \mathrm{~B}$ were sedimented through glycerol gradients and the resulting fractions assayed for $\mathrm{CP} 1 \mathrm{~A}$ and $\mathrm{CP} 1 \mathrm{~B}$ binding activities (Figure 5). CP1B activity derived from phosphocellulose fraction $C$ peaked in gradient fraction 3 , corresponding to a Svedberg coefficient of approximately 2.7 S (Figure 5, top panel, lane 5). CP1A activity derived from $D E A E$ fraction $A B$ peaked in gradient fraction 4 , corresponding to a Svedberg coefficient of $3.7 \mathrm{~S}$ (Figure 5 , second panel from top, lane 6 ). When fractions $A B$ and $C$ were mixed and preincubated prior to loading on the glycerol gradient, both CP1A and CP1B activities sedimented considerably more rapidly and both activities peaked in fraction 7 (Figure 5 , bottom two panels, lane 9). 
C

$A B$

C
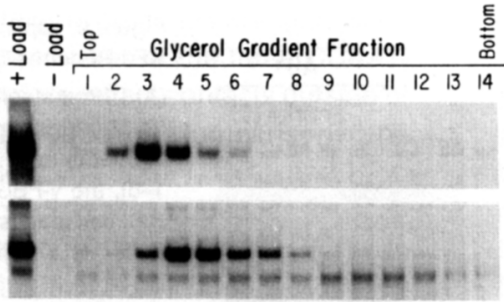

$A B, C$

$\mathrm{AB}$

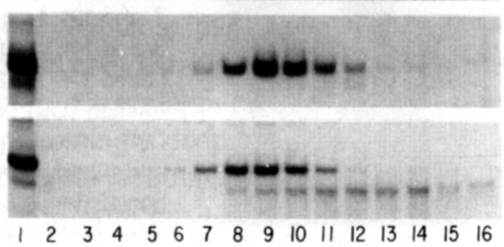

Figure 5. Glycerol Gradient Sedimentation Analysis of CP1A and CP1B Activities

Two hundred and fifty micrograms of HeLa fraction [C], containing partially purified CP1B (top panel), $1.2 \mathrm{mg}$ of HeLa fraction [AB], containing partially purified CP1A (second panel from top), or a mixture of $250 \mu \mathrm{g}$ of fraction [C] $3.7 \mathrm{~S}$ and $1.2 \mathrm{mg}$ of traction $[A B]$ (bottom two panels) were incubated for $10 \mathrm{~min}$ at $30^{\circ} \mathrm{C}$. Reactions were layered onto $10 \%-30 \%$ glycerol gradients and sedimented at $45,000 \mathrm{rpm}$ for $19 \mathrm{hr}$ at $4^{\circ} \mathrm{C}$. Fourteen tractions ( $275 \mu$ l each) wero taken from each gradient and assayed for either CP1A activity or CP1B activity. The top of the gradient was fraction 1 . In a parallel gradient, $50 \mu \mathrm{g}$ each of ovalbumin, bovine serum albumin, carbonic anhydrase, cytochrome $\mathrm{C}$ and catalase were sedimented, and portions of each fraction were analyzed by SDS-polyacrylamide electrophoresis. To assay for CP1A activity (second panel from top, and bottom panel), 20,000 $\mathrm{cpm}(0.3 \mathrm{ng})$ of the MLP-containing probe. RMC. was added to a standard binding reaction containing a mixture of $7.5 \mu \mathrm{g}$ of fraction [C] (lanes $1-16$ ), and either $36 \mu \mathrm{g}$ fraction of $[A B]$ (lane 1), $7 \mu \mathrm{l}$ of glycerol gradient buffer containing no protein (lane 2 ), or $7 \mu l$ of gradient tractions $1-14$ (lanes 3-16, respectively). To assay for $\mathrm{CP} 1 \mathrm{~B}$ activity (top panel and second panel from bottom), 20,000 cpm (0.3 ng) of the MLP-containing probe, RMC, was added to a standard binding reaction containing a mixturo of $36 \mu \mathrm{g}$ of fraction $[\wedge \mathrm{B}$ ] (lanes 1 16), and either $7.5 \mu \mathrm{g}$ of fraction [C] (lane 1), $7 \mu \mathrm{l}$ of glycerol gradient buffer containing no protein (lane 2), or $7 \mu \mathrm{l}$ of gradient fractions 1-14 (lanes 3-16, respectively). Binding reactions were analyzed by native gel electrophoresis as above. Following autoradiography, panels corresponding to the bound complexes formed on the MLP probe were excised and mounted together for direct comparison. Svedberg coefficients were determined by comparison of the activity peak in each gradient to the sedimentation profile of protein standards. The Svedberg coefficients corresponding to the activity peak from each gradient are indicated to the right of each panel

This sedimentation rate corresponded to a Svedberg coefficient of $5.3 \mathrm{~S}$, indicating that $\mathrm{CP} 1 \mathrm{~A}$ and $\mathrm{CP} 1 \mathrm{~B}$ were present as part of a larger complex. This complex was stable at $4^{\circ} \mathrm{C}$ over the period of $16 \mathrm{hr}$ required for centrifugation. Binding activity assayed in the absence of exogenously added fractions $\mathrm{AB}$ or $\mathrm{C}$ indicated that glycerol gradient fraction 7 contained all of the components required for specific CP1 binding (data not shown).

Interestingly, in the gradients containing both CP1A and $\mathrm{CP} 1 \mathrm{~B}$ activities, the activity peaks corresponding to the individually sedimented factors at $2.7 \mathrm{~S}$ and $3.7 \mathrm{~S}$ were not detectable (Figure 5, bottom two panels, lanes 3 and 4). Since roughly equivalent amounts of CP1A and CP1B activity were loaded onto the gradient (data not shown), it is possible that the two activities efficiently associated with one another. If this occurred, it can be inferred that CP1A and $\mathrm{CP} 1 \mathrm{~B}$ bind to each other with high affinity

The Svedberg coefficients of CP1A and CP1B correspond to molecular weights of approximately 45 and 25 $\mathrm{kd}$, respectively, assuming they are globular proteins. The sedimentation rate of the $\mathrm{CP} 1 \mathrm{~A} / \mathrm{CP} 1 \mathrm{~B}$ complex corresponds to a molecular weight of approximately 140-150 kd. Thus if $\mathrm{CP} 1$ and its component suburits behave as globular proteins, it is probable that the complex formed in solution is composed of more than a monomer of CP1A and a monomer of $\mathrm{CP} 1 \mathrm{~B}$. $\mathrm{CP} 1$ may in fact be a heterologous complex composed of two molecules each of CP1A and $\mathrm{CP} 1 \mathrm{~B}$. However, since there is no information regarding the shape of these molecules, and since there may be a significant conformational change following their association, the stoichiometry of components contained in CP1 cannot be determined from this experiment

\section{CP1A and CP1B Are Both Present in the CP1-DNA Complex}

If a CP1A/CP1B heterologous complex is in fact the species that specifically binds to DNA, then both molecules should copurify during DNA-affinity chromatography. CP1 was purified by chromatography on a specific, MLP. containing DNA-affinity column. Affinity-purified CP1 was subsequently subjected to phosphocellulose chromatography under conditions similar to those that separate CP1A from CP1B (Figure 6; see Experimental Procedures). Following chromatography, each fraction was assayed for the presence of CP1A and CP1B activities. The affinity-purified $\mathrm{CP} 1$ binding activity loaded onto the column could not be detected either in the $0.06 \mathrm{M} \mathrm{KCl}$ flowthrough from the column or in the $0.6 \mathrm{M} \mathrm{KCl}$ eluate (Figure 6 , lanes 4,5 , and 8 ). Addition of partially purified $\mathrm{CP} 1 \mathrm{~B}$ to the flowthrough fraction resulted in a dramatic stimulation of specific CP1 binding activity (Figure 6, lane 7). Conversely, addition of partially purified $C P 1 A$ to the flowthrough fraction had no effect upon binding activity (Figure 6 , lane 6). This suggested that CP1A was present in the flowthrough fraction. Similarly, addition of partially purified CP1A to the $0.6 \mathrm{M} \mathrm{KCl}$ phosphocellulose fraction resulted in a dramatic stimulation of binding activity. Conversely, addition of partially purified CP1B to this same fraction had no effect upon binding activity (Figure 6 , lanes 9 and 10). This suggested that CP1B was present in the $0.6 \mathrm{M}$ phosphocellulose fraction. The eluate from a DNA-affinity column formed with a control fragment contained neither CP1A nor CP1B (data not shown). Thus, CP1 purified by DNA-affinity chromatography contained both $\mathrm{CP} 1 \mathrm{~A}$ and $\mathrm{CP} 1 \mathrm{~B}$ activities. Therefore not only are 


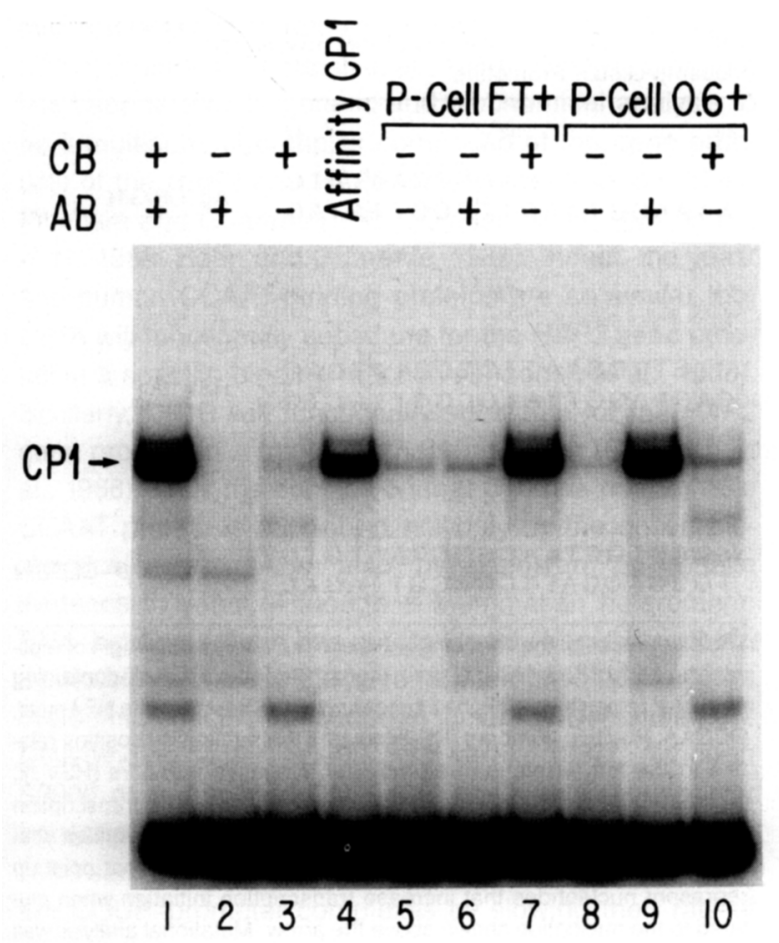

Figure 6. CP1A and CP1B Are Present in the CP1-DNA Complex CP1 activity was purified by DNA-affinity chromatography as described in Experimental Procedures, and loaded onto a phosphocellulose column in buffer $A+60 \mathrm{mM} \mathrm{KCl}$. The flowthrough (FT) was collected, and the column was eluted with Buffer $\mathrm{A}+0.6 \mathrm{M} \mathrm{KCl}$ as described in Experimental Procedures. 20,000 cpm (0.1 ng) of an MLP probe containing sequences from -108 to -62 was incubated in a standard CP1 binding reaction (lanes 1-10) containing either $12 \mu \mathrm{g}$ of CP1A-containing fraction $[A B]$ (lancs $1,2,6$, and 9 ), $4 \mu \mathrm{g}$ of $C P 1 B$ containing fraction [CB] (lanes 1, 3, 7, and 10), $1 \mu$ l of affinity-puritied CP1 (lane 4), $1 \mu \mathrm{l}$ of the affinity-purified CP1 phosphocellulose flowthrough (P-Cell FT) fraction (lanes 5-7), or $1 \mu$ of the affinity-purified CP1 phosphocellulose $0.6 \mathrm{M} \mathrm{KCl}$ (P-Cell 0.6) eluate (lanes 8-10). Lane 1 contained a mixture of partially purified $C P 1 A$ activity $([A B])$ and partially purified $C P 1 B$ activity ([CB]). Lanes 2 and 3 contained partially purified CP1A alone, and partially purified CP1B alone, respectively. Lane 4 contained $1 \mu \mathrm{I}$ of affinity-purified CP1. In lanes 5-7, $1 \mu$ of the affinity-purified CP1 phosphocellulose flowthrough fraction was incubated either alone (lane 5), with partially purified CP1A (lane 6), or with partially purified CP1B (lane 7). In lanes 8-10,1 $\mu$ l of the affinity purificd CP1 phospho cellulose $0.6 \mathrm{M}$ eluate was incubated either alone (lane 8 ), with partially purified CP1A (lane 9), or with partiaily purified CP1B (lane 10). Binding reactions were analyzed by native gel electrophoresis as above.

CP1A and CP1B both required for DNA-binding activity, they are also each present in the CP1-DNA complex.

\section{Discussion}

We have identified three distinct proteins, CP1, CP2, and NF-I, which are present in extracts of HeLa cells and which bind to different subsets of promoter elements containing the sequence CCAAT. Each of these proteins has been shown to make critical contacts within the CCAAT pen. tanucleotide sequence by methylation interference analysis and by competition binding analysis with mutants harboring alterations in the CCAAT element. The three
CCAAT-binding proteins were distinct since first, each formed a specific protein-DNA complex of unique mobility and appearance during native gel electrophoresis: second, each made a unique set of contacts with its binding site as assayed by methylation interference; third, each bound with a unique pattern of affinities to a variety of promoters containing CCAAT elements; and fourth, each of the three CCAAT proteins could be separated chro. matographically.

How do the CCAAT-binding proteins identified here $\mathrm{s}=$ late to those that have previously been identified? CP1 binds with high affinity to promoters that include human $\alpha$-globin, human hsp70, $\mathrm{H}-2 \mathrm{~K}^{b}$, the adenovirus MLP, and the MSV LTR. Based upon the consensus sequence for CP1 (Table 1) and published methylation interference patterns for other CCAAT-binding factors, CP1 may be similar or idenlical to CCAAT-binding factors that bind to the sea urchin sperm histone $\mathrm{H} 2 \mathrm{~B}$ promoter, the human thymidine kinase promoter, the human hsp70 promoter, the mouse $\alpha$-globin promoter, and the MHC class $\| E_{i t}$ promoter (Barberis et al., 1987; Knight et al., 1987; Wu et al., 1987; Cohen et al., 1986; Dorn et al., 1987).

It is more difficult to establish the relationship of CP2 to previously described CCAAT-binding factors. CP2 binds with high affinity to CCAAT elements present in the $\gamma$-FBG promoter, the $\mathrm{H}-2 \mathrm{~K}^{\mathrm{b}}$ promoter, and the MOPC $-41 \mathrm{~V}$ : promoter (see Table 1 for consensus sequence). Proteins binding to these elements have not been previously described.

A previously characterized high-affinity binding site was used to detect NF-l (Rosenfeld et al., 1987). This probe generated a heterogeneous pattern of specific proteinDNA complexes with HeLa cell extracts in the gel elec trophoresis DNA-binding assay. This pattern is highly distinctive, and essentially identical to complexes generated by affinity-purified NF-I (Rosenfeld et al., 1987; Jones et al., 1987). As anticipated from previous results, the formation of all of these complexes was eliminated by a double point mutation in the NF-l binding site (Rosenfeld et al., 1987). Finally, the methylation interference pattern observed for the heterogeneous set of NF-I protein-DNA complexes was identical to that reported for the binding of purified NF-I (De Vries et al., 1987). On this basis, we conclude that the collection of proteins that specifically binds to the probe containing the consensus NF-I binding site is NF-I.

It has previously been reported that a single CCAATbinding protein, CTF/NF-I, is both a promoter-specific transcription factor (CTF) for RNA polymerase II and an initiation factor for adenovirus DNA replication (NF-I) (Jones et al., 1987). NF-I is a cellular protein that binds with highaffinity to the adenovirus origin of replication and is re. quired for the initiation of replication (Nagata et al., 1983; Leegwater et al., 1985; Rosenfeld et al., 1987). CTF has been defined as a cellular DNA-binding protein that specifically stimulates transcription from the human a-globin promoter, the HSV thymidine kinase promoter, and the human hsp70 promoter by selective recognition of CCAAT elements in these promoters (Jones et al., 1985; Jones et al., 1987; Morgan et al., 1987). CTF has also been reported 
to bind to CCAAT elements in the MSV LTR and the human $\beta$-globin promoter (Jones et al., 1985; Jones et al., 1987). Interestingly, these five CCAAT elements bound by CTF/ NF-I are also bound by CP1 with virtually the same pattern of affinities, with the important exception that CP1 does not bind with appreciable affinity to the adenovirus origin of replication or to the NF-I consensus sequence. Moreover, the group of CCAAT-binding proteins that recognizes the NF-I consensus sequence probe does not bind with appreciable affinity to any of the CCAAT elements that are recognized by $C P 1$. Thus, the high-affinity binding specificities of CP1 and NF-I are entirely nonoverlapping. However, the sum of the binding specificities of CP1 and NF-I are equivalent to the proposed binding specificity of the putative CTF/NF-I proteins.

Mutational analysis of the HSV tk and $\beta$-globin promoters suggests that $\mathrm{CP1}$, and not NF-1, is likely to be responsible for the transcription stimulation mediated by the CCAAT elements in these promoters (Graves et al., 1986; Myers et al., 1986; Charnay et al., 1985). Several mutations that affect the transcription efficiency of these promoters do not alter sequences shared with the NF-I consensus sequence (Table 2; Rosenfeld et al., 1987; Leegwater et al., 1985). Each of these mutations, however, does alter sequences shared with the consensus sequence of CP1 (Table 1). Specifically, the positions of two mutations that decrease transcription from these two promoters (HSV tk -88 [A to $\mathrm{C}$ ]; $\beta$-globin -72 [C to $\mathrm{T}]$ ) and three mutations that increase transcription from these two promoters (HSV tk -87 [G to C]; HSV tk -80 [C to $\mathrm{G}$ ]; $\beta$-globin $-79[G$ to $A]$ ) correspond to sites where base substitutions have no effect on the affinity of NF-I binding (Table 2; Graves et al., 1986; Myers et al., 1986; Rosenfeld et al., 1987). In contrast, nucleotides at each of these positions are conserved in high-affinity $\mathrm{CP} 1$ binding sites. For all five mutations, those which increase transcriptional efficiency increase the degree of similarity to the CP1 consensus sequence, while those that decrease transcriptional efficiency decrease the degree of similarity to the $\mathrm{CP} 1$ consensus sequence. Thus, the effect on transcriptional efficiency of a number of mutations in the CCAAT elements of the HSV tk and mouse $\beta$-globin promoters are more readily correlated with $\mathrm{CP} 1$ binding specificity than with NF-I binding specificity.

Surprisingly, each of the three CCAAT-binding proteins, CP1, CP2, and NF-1, appear to be composed of at least two different subunits. This unique property was investigated most thoroughly for CP1. CP1 binding activity in HeLa extracts was lost following phosphocellulose chromatography, and was only reconstituted when two partially purified fractions containing $\mathrm{CP} 1 \mathrm{~A}$ and $\mathrm{CP} 1 \mathrm{~B}$ were combined. Neither CP1A nor $\mathrm{CP} 1 \mathrm{~B}$ alone exhibited a significant amount of DNA-binding activity. However, DNA-affinity purified CP1 contained both CP1A and CP1B activities, demonstrating that both polypeptides were present in the CP1-DNA complex. Moreover, glycerol gradient sedimentation revealed that $\mathrm{CP} 1 \mathrm{~A}$ and $\mathrm{CP} 1 \mathrm{~B}$ form a stable complex in solution in the absence of a CP1 binding site. The simplest interpretation of these results is that CP1 is a multisubunit protein composed of heterologous subunits.
Table 2. Mutational Analysis of the HSV tk and Mouse $\beta$-Globin Promoters

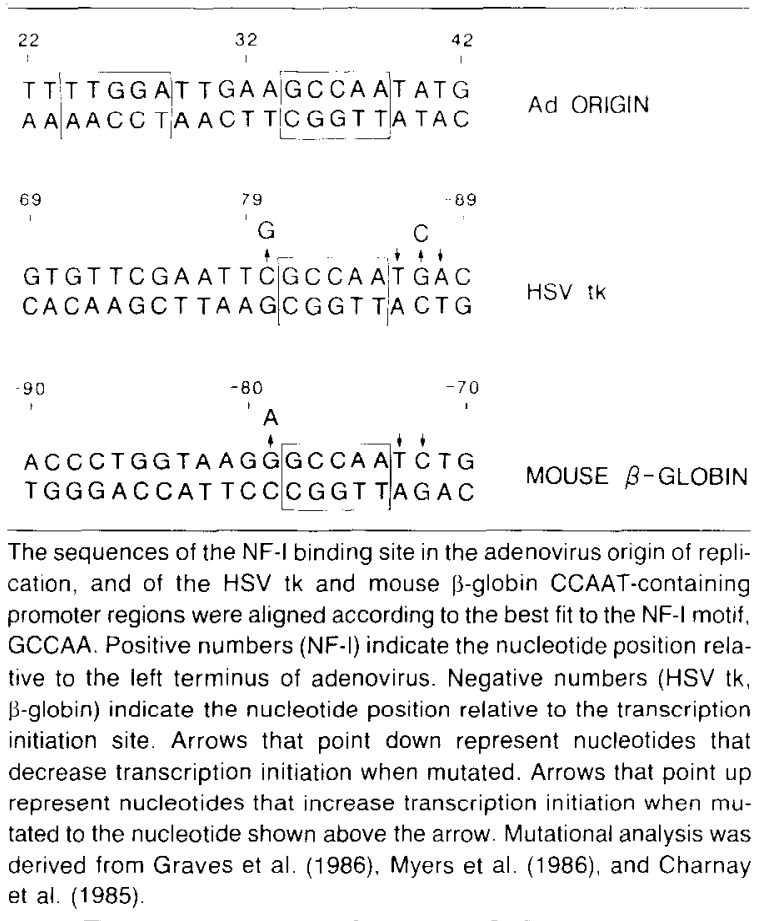

The CCAAT-binding proteins CP2 and NF-I showed a two-factor dependence for DNA-binding which was very similar to that exhibited by CP1. Each required the mixing of two fractions in order to reconstitute maximum binding activity. It is potentially important to note that the two factor binding requirement was not as stringenlly observed for CP2 and NF-I as it was for CP1. High concentrations of CP2B or NF-IB alone, but not of CP1B alone, were capable of specific DNA-binding (see below). The chromatographic properties of the fractions containing the CP1A, CP2A, and NF-IA activities were remarkably similar. Nevertheless, CP1A, CP2A, and NF-IA could be shown to be chromatographically distinct and therefore most likely reflect the activities of different polypeptides. The complementing group of activities, CP1B, CP2B, and NF-IB, also behaved similarly during chromatography, but CP1B was shown to be chromatographically distinct from CP2B and NF-IB. Further evidence also suggested that CP2B and NF-IB were distinct. Although we favor the model that CP2 and NF-I are also multisubunit proteins composed of heterologous subunits, this must be considered a hypothesis at present. However, this possibility is strengthened by the extensive similarity between these three CCAAT-binding ractors in their recognition sequences, their apparent iwo-factor binding dependence, and the similar chromatographic behavior of each of their components. Thus we suggest that $\mathrm{CP1}, \mathrm{CP2}$, and NF-I are members of a family of evolutionarily related, heteromeric CCAAT-binding proteins.

Recently, the CCAAT-binding protein CP1 was shown to be highly homologous to a yeast CCAAT-binding protein 
that activates transcription from the iso-1-cytochrome $\mathrm{C}$ (CYC1) promoter (Chodosh et al., 1988). This yeast protein has been shown by genetic and biochemical analysis to be a multisubunit complex composed of the gene products of the HAP2 and HAP3 loci (Guarente et al., 1984; Pinkham and Guarente, 1985; Olesen et al., 1987; Hahn et al., 1988; Hahn and Guarente, 1988). In fact, the yeast and human CCAAT-binding proteins are so similar that CP1A will functionally substitute for the HAP3 gene product in a specific binding reaction (Chodosh et al., 1988). Similarly, CP1B will functionally substitute for the HAP2 gene product in a specific binding reaction (Chodosh et al., 1988). Thus the conclusion that CP1 is a heteromeric CCAAT protein is supported not only by the above biochemical evidence but also, by extension, by genetic evidence in yeast. Although a mammalian heteromeric DNA-binding protein has not previously been described, a possible example is the specific interaction between the ovalbumin-specific transcription factor, COUP, and a nonDNA-binding factor, S300Il (Tsai et al., 1987). Although S300ll does not bind DNA, it is absolutely required for transcription of the ovalbumin promoter, but not for the SV40 early promoter. It appears that S300II is able to stabilize COUP-promoter complexes by slowing their rate of dissociation.

The factors, CP1A, CP2A, and NF-IA flow through negatively charged columns while the factors $\mathrm{CP} 1 \mathrm{~B}, \mathrm{CP} 2 \mathrm{~B}$, and NF-IB bind to DNA-cellulose and to other negatively charged columns. This suggests that the latter set may possess a degree of intrinsic DNA-binding activity. Specific DNA-protein complexes were observed with fractions containing only CP2B or NF-IB. Although these complexes could reflect the intrinsic binding of the single $B$ factor, it is impossible to exclude the potential presence of contaminating $A$ factor. The methylation interference pattern of the complex generated by $\mathrm{CP} 2 \mathrm{~B}$ alone was similar to that generated by $C P 2$, but methylation at many more sites disrupted the CP2B-DNA complex. This would be expected if the affinity of the CP2B-DNA complex was lower than that of the CP2-DNA complex. By extension, we would predict that NF-IB could also be footprinted on DNA in the absence of NF-IA. Therefore, polypeptides encoded by the CDNA clones of either CP2B or NF-IB would specifically bind to their respective recognition sites. However, we would predict that the affinity of the cloned protein would be lower than that of the complete heteromer, and that the heteromer is the active form in vivo.

What is the functional significance of heteromeric CCAAT-binding proteins? A greater variety of regulatory options is available to a single protein that is composed of two or more subunits, each of which may be regulated independently in response to tissue-specific, temporal or environmental signals. In addition, the interchange of subunits among such proteins would provide an additional level of combinatorial complexity to gene regulation. If one of the polypeptides in the heteromer contains the DNA-binding specificity, then exchange of the second polypeptide with another factor could play an important role in the transcriptional regulation of a particular promoter. For example, CP1A-like factors may affect transcrip- tional activation by conferring a particular specificity on. or increasing the efficiency of transcriptional activation of. CP1B-like factors. This model would readily help explain how some molecules which appear to lack intrinsic DNAbinding activity are able to modulate the transcription activity of DNA-binding proteins (Kingston et al., 1985). Thus, the trans-activator protein ElA of adenovirus may be a CP1A-like molecule. Conversely, this model could also help explain how DNA-binding proteins of apparently limited specificity are able to specifically activate transcription. The cellular proto-oncogene products c-myc and $c$-fos may function by this mechanism and may therefore be CP1B-like molecules.

\section{Experimental Procedures}

\section{Plasmids}

Plasmid pRMC was prepared by subcloning a 127 bp EcoRl-Haelll fragment from $p L P$ into EcoRI-Smal-digested pUC13. PLP, whose construction has previously been described (Chodosh et al., 1986), contains Ad 2 MLP sequences from -174 to +33 . The $5^{\prime}$ deletion/linker scanning mutant, $p \wedge 108-M L P$, was prepared by digesting the $161 \mathrm{bp}$ EcoRl-Hindlll tragment of pRMC with Mboll, blunting the ends with T4 DNA polymerase, and digesting the resulting Mboll-Hindlll fragment with BamHI. The Mboll-BamHI fragment was subcloned into HincllBamHI-digested pRW, a plasmid containing Ad 2 MLP sequences from -51 to +33 whose construction has previously been described (Chodush et al., 1986). The resulting plasinid, $p \Delta 108-M L P$, contains Ad 2 MLP sequences from -108 to +33 , with a linker-scanning mutation of the MLTF-binding site that replaces sequences from -62 to -53 with a pUC13 polylinker sequence containing a BamHI restriction site. Plasmid paGBCCAAT contains human $\alpha$-globin sequences from -81 to -58 , and was prepared by inserting a synthetic oligonucleotide of sequence CTAGACTCCGCGCCAGCCAATGAGCGCCGT into the Xbal site of pUC18. Plasmid paGBCCAAT-dm is identical to paGBCCAAT with the exception that the inserted oligonucleotide differs at two positions, and contains the sequence CTAGACTCCGCGCCAGCGAGTGAGCGCCGT. Plasmid p $\gamma$ FBG-95, whose construction has previously been described (Chodosh et al., 1987), cuntains rat $\gamma$-fibrinugen sequences from -95 to +35 . The plasmids pID $-62 /-54$, pID $-65 /-54$, and plD-74/-54, which were kind gifts from J. Morgan, are internal deletion mutants of the rat $\gamma$-FBG promoter and have been described previously (Chodosh et al., 1987; Morgan et al., 1988). Plasmid pNF-I contains a high-affinity NF-I binding site derived by mutating a single position of the adenovirus origin of replication. This mutant has previously been characterized as pUpm28 (Rosenfeld et al., 1987). pNF-I was constructed by inserting a synthetic oligonucleotide of sequence GATCATTTTGGCTTGAAGCCAATATGA into the BamHI site of pUC13. The plasmid pNF-I-dm was prepared identicaliy to $\mathrm{pNF}-1$, with the exception that the inserted oligonucleotide differed al two positions, and contained the sequence GATCATTTTTGCTTGAAGCAAATATGA. Plasmid pRIB contains 84 to 100 map units of Ad 5 cloned into the EcoRI site of pBR322 and has been previously described (Fire et al., 1981). The plasmid $\mathrm{pH}-2 \mathrm{~K}^{\mathrm{b}} \Delta 15$ (A. Baldwin, unpublished results) was derived from p365H2KCAT (Baldwin and Sharp, 1987), and contains sequences from -65 to +3 of the mouse class I major histocompatibility $\mathrm{H}-2 \mathrm{~K}^{\mathrm{b}}$ gene subcloned into pUC-CAT (gift from M. Gilman). The plasmid pH2KCCAAT-72 contains sequences from the $\mathrm{MHC} \mathrm{H-2K^{b }}$ promoter between -90 and -64 and was prepared by inserting a

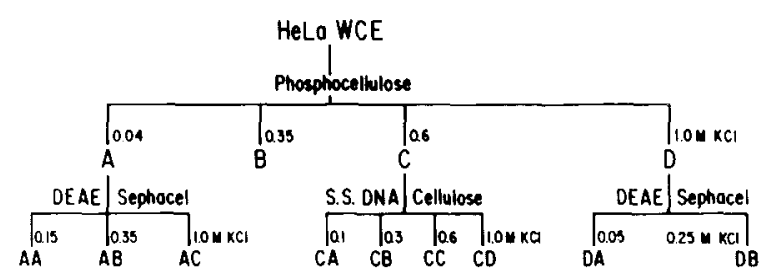


synthetic oligonucleotide of sequence GATCCGCGCCACCCAATGGGGGTAAGAGCTG into the BamHI site of pUC13. The plasmid p328pUC, a gift from $D$. Galson, contains mouse $\beta$-globin sequences from -344 to -15 and has been described previously (Galson and Housman, 1988). The plasmid pSPIgV $k$ gene was a gift from $N$. Speck and contains the $250 \mathrm{bp}$ StaNI promoter fragment of the MOPC-41 $\mathrm{V}_{k}$ gene encompassing sequences upstream of -47 (Singh et al., 1986). All plasmids constructed by inserting synthetic oligonucleotides into pUC13 or pUC18 were sequenced to confirm single copy insertion and proper sequence.

\section{Probes for Gel Electrophoresis DNA-Binding Assay}

All probes were prepared by end-labeling DNA fragments with Klenow and either $\alpha-\left[{ }^{32} \mathrm{P}\right] \mathrm{dATP}$ or $\alpha-\left[{ }^{32} \mathrm{P}\right] \mathrm{dCTP}$, and were isolated by agarose gel electrophoresis onto NA-45 DEAE-membrane followed by elution in a buffer consisting of $10 \mathrm{mM}$ Tris- $\mathrm{HCl}(\mathrm{pH} \mathrm{7.9)}, 1 \mathrm{mM}$ EDTA, and $1.0 \mathrm{M}$ $\mathrm{NaCl}$ according to the supplier's recommendations (Schleicher \& Schuell). The 161 bp MLP-containing probe HMC was prepared by end-labeling an EccRl-Hindlll digest of pRMC. The 74 bp MLPcontaining probe, $\Delta 108$, which contains MLP sequences from -108 to -62 , was prepared by end-labeling a BamHI-HindIII digest of $p \Delta 108$ MLP. The 90 bp $\gamma$-fibrinogen-containing probe, $\gamma$-FBG, which contains $\gamma$-FBG sequences from -95 to -39 , was prepared by end-labeling an EcoRI/Hindlll digest of pyFBG-95. The 77 bp probe, NF-I, which contains sequences corresponding to +21 to +45 of the left terminus of Ad 2 with a point mutation at +28 , was prepared by end-labeling an EcoRI/Hindlll digest of pNF-I.

\section{Competitor DNA Fragments for Gel Electrophoresis DNA-Binding Assay}

The competitor DNA fragment, MLP (MLP-108), was prepared by digesting $\mathrm{p} \triangle 108-\mathrm{MLP}$ with $\mathrm{BamHI}$ and $\mathrm{HindIII}$, and isolating the $74 \mathrm{bp}$ fragment ( -108 to -62 relative to the MLP cap site). The competitor fragment, MLP-53, was prepared by digesting $\mathrm{p} \Delta-108-\mathrm{MLP}$ with EcoRI and BamHI, and isolating the 98 bp fragment $(-53$ to +33$)$. The competitor fragment, $\gamma$-FBG, was prepared by digesting $p \gamma F B G-95$ with EcoRl, and isolating the $90 \mathrm{bp}$ fragment ( 95 to 39 ). The competitor fragments, ID-62/-54, ID-65/-54, and ID-74/-54, were prepared by digesting the plasmid corresponding to each with BstEll and BstXI, and isolating the 122,119 , or 110 bp fragment, respectively ( -95 to +35 with internal deletion of -62 to $-54,-65$ to -54 , or -74 to -54 , respectively). The competitor fragment, NF-I, was prepared by digesting pNF-I with EcoRl and Hindlll, and isolating the $77 \mathrm{bp}$ fragment (corresponding to +21 to +45 of the left terminus of $\mathrm{Ad} 2$ with a point mutation at +28 ). The fragment, NF-I-dm, was prepared by digesting pNF-I-dm with EcoRI and HindIII, and isolating the $77 \mathrm{bp}$ fragment. The fragment, Ad origin, was prepared by digesting $\mathrm{pRIB}$ with Smal and EcoRl, and isolating the 580 bp fragment ( -329 to +246 ). The competitor fragment, $\alpha$-globin, was prepared by digesting paGBCCAAT with EcoRl and Hindlll, and isolating the $80 \mathrm{bp}$ fragment $(-81$ to -58$)$. The competitor fragment, $a-g$ lobin-dm, was prepared by digesting $\alpha$-GBCCAAT-dm with EcoRI and Hindlfl, and isolating the 80 bp fragment. The competitor fragment, $\mathrm{H}-2 \mathrm{~K}-51$, was prepared by digesting $\mathrm{pH}-2 \mathrm{~K}^{\mathrm{b}} \Delta 15$ with $\mathrm{Xhol}$ and EcoRl, and isolating the $335 \mathrm{bp}$ fragment $(-65$ to +3$)$. The competitor fragment, $\mathrm{H}-2 \mathrm{~K}-72$, was prepared by digesting $\mathrm{pH} 2 \mathrm{KCCAAT}-72$ with ECORI and Hind III, and isolating the 81 bp fragment $(-90$ to -64$)$. The HSV tk competitor fragment was prepared by annealing the gel-purified 31 nucleotide synthetic oligonucleotide of sequence CTAGATGT TCGAATTCGCCAATGACAAGACT to the complementary oligonucleotide CTAGATCTCT TGTCATT. GGCGAAT TCGAACAT (-94 to -70). The competitor fragment, $\beta$-globin, was prepared by digesting p328pUC with BamHI and Hindlll and isolating the $330 \mathrm{bp}$ fragment $(-344$ to -15$)$. The competitor fragment, $V_{k}$ was prepared by digesting pSPIgV $_{k}$ with EcoRI and HindIII, and isolating the $300 \mathrm{bp}$ fragment $(-47$ to -297$)$. The competitor fragment, pUC-18, was prepared by digesting pUC18 plasmid with EcoRl and HindIII, and isolating the $50 \mathrm{bp}$ polylinker. All fragments were purified by agarose gel electrophoresis onto NA-45 as above. DNA fragment concentrations were estimated by comparison with $E$. coli DNA digested with Hincll using the ethidium bromide dot method (Maniatis et al., 1982)
Gel Electrophoresis DNA-Binding Assay

Protein-DNA complexes were resolved on low ionic strength native polyacrylamide gels as described (Carthew et al., 1985), with several modifications. Protein samples were incubated with approximately $20,000 \mathrm{cpm}(0.1-0.3 \mathrm{ng})$ of an end-labeled double-stranded DNA fragment in the presence of $2.0 \mu \mathrm{g}$ poly $(\mathrm{dl}-\mathrm{dC})$ poly $(\mathrm{dl}-\mathrm{dC})$ in a final volume of $10 \mu \mathrm{l}$. Incubations were carried out at $30^{\circ} \mathrm{C}$ for $10-30 \mathrm{~min}$. All binding reactions contained $12 \%$ glycerol, $12 \mathrm{mM}$ HEPES-NaOH $(\mathrm{pH} 7.9), 4$ $\mathrm{mM}$ Tris- $\mathrm{HCl}(\mathrm{pH} 7.9), 1 \mathrm{mM}$ EDTA, $0.6 \mathrm{mM}$ dithiothreitol, and $300 \mu \mathrm{g} / \mathrm{ml}$ bovine serum albumin. In addition, CP1 and CP2 binding reactions contained $60 \mathrm{mM} \mathrm{KCl}$, whereas $\mathrm{NF}-\mathrm{I}$ binding reactions contained 150 $\mathrm{mM} \mathrm{KCl}$ and $5 \mathrm{mM} \mathrm{MgCl}_{2}$ except as indicated. Following electrophoresis, gels were dried onto Whatmann $3 \mathrm{MM}$ and visualized by autoradiography on Kodak XAR-5 film.

\section{Methylation Interference Assay}

The procedure of Siebenlist et al. (1980) was used with several modifications. Probes for methylation interference assays were prepared as above, except that each was uniquely end-labeled. In order to label the coding strand, $p \triangle 108-M L P, p \gamma F B G$, and $p N F-I$ were first digested with BamHI, EcoRI, and EcoRI, respectively. In order to label the noncoding strand, pA108-MLP, pyFBG, and pNF-I were first digested with HindlII, $\mathrm{BamHI}$ and HindIII, respectively. Digested plasmids were end-labeled with Klenow and either $\alpha-\left[{ }^{32} P\right] d A T P$ or $\alpha-\left[{ }^{32} P\right] d C T P$. Following heat inactivation, plasmids $\mathrm{p} \Delta 108 \mathrm{MLP}, \mathrm{p} \gamma \mathrm{FBG}$, and pNF-I labeled on the coding strand were redigested with HindllI, BamHI, and Hindlll, respectively. Plasmids $p$ A108-MLP, p $F$ FG, and pNF-I labeled on the noncoding strand were redigested with BamHI, EcoRl, and EcoRI, respectively. Probes were partially methylated with dimethylsulfate (Maxam and Gilbert, 1980), purified, and used as substrate in a standard binding reaction as above, with the exception that reactions were scaled up to $50 \mu \mathrm{l}$, and contained $200,000 \mathrm{cpm}$ of the appropriate probe in addition to $10 \mu \mathrm{g}$ poly(dl-dC)-(dl-dC), $180 \mu \mathrm{g}$ fraction [AB], and 58 $\mu \mathrm{g}$ fraction [CB]. A mock binding reaction lacking fractions $[A B]$ or $[C B]$ was performed in parallel. After incubation at $30^{\circ} \mathrm{C}$ for $30 \mathrm{~min}$, binding reactions were loaded onto native polyacrylamide gels and electrophoresed as above. Brief autoradiography at $4^{\circ} \mathrm{C}$ identified free and bound DNA-containing complexes which were excised from the native polyacrylamide gel and embedded in an agarose gel. Labeled DNA was electrophoresed from the polyacrylamide gel slices, through the agarose matrix, and onto NA-45 DEAE-membrane. DNA bound to the NA-45 membrane was eluted as above, purified, piperidine-cleaved, electrophoresed on a $10 \%$ polyacrylamide- $8 \mathrm{M}$ urea $0.3 \mathrm{~mm}$ thickness gel, and visualized by autoradiography. Gels from which complexes had been excised were revisualized by autoradiography to confirm that the appropriate complexes had been accurately excised.

\section{Affinity Purification of CP1}

CP1 was affinity-purified using a modification of the previously described streptavidin-biotin technique (Chodosh et al., 1986). The HincllEcoRl fragment of PRMC was isolated and biotinylated wilt biotirdUTP and Klenow fragment (Chodosh et al., 1986). One hundred and forty-four nanograms of the $145 \mathrm{bp}$ biotinylated fragment was incubated with $100 \mu \mathrm{g}$ poly $(\mathrm{dl}-\mathrm{dC}) \cdot(\mathrm{dl}-\mathrm{dC}), 250 \mu \mathrm{g} / \mathrm{ml} \mathrm{BSA}, 2.4 \mathrm{mg}$ fraction $[\mathrm{AB}]$, and $0.87 \mathrm{mg}$ fraction [CB] in a final volume of $367 \mu \mathrm{l}$ under standard $\mathrm{CP} 1$ binding conditions at $30^{\circ} \mathrm{C}$ for $60 \mathrm{~min}$. Eight hundred and fifty nanograms of streptavidin (Apcel) were added, and the reaction continued for an additional $15 \mathrm{~min}$. Reactions were chilled on ice, added to $30 \mu$ l of preequilibrated biotin-cellulose (Pierce), resuspended, and gently mixed at $4^{\circ} \mathrm{C}$ for $30 \mathrm{~min}$. The reaction was centrifuged at 2000 $\mathrm{rpm} \times 1 \mathrm{~min}$ and the biotin-cellulose pellet was washed five times with $10 \mathrm{ml}$ each of cold binding buffer, transterred to a clean lube, poured into a P1000 Eppendorf pipet tip plugged with siliconized glass wool, and eluted with $200 \mu$ lof Buffer $\mathrm{A}+1.0 \mathrm{M} \mathrm{KCl}+200 \mu \mathrm{g} / \mathrm{ml} \mathrm{BSA}$. Fractions containing $C P 1$ activity were pooled and dialyzed against Buffer $\mathrm{A}+0.06 \mathrm{M} \mathrm{KCl}$.

\section{Extracts and Chromatography}

HeLa whole-cell extracts were prepared as previously described (Manley et al., 1980). Chromatography of HeLa whole cell extract to generate fractions $[\mathrm{A}],[\mathrm{AB}],[\mathrm{C}]$, and $[\mathrm{CB}]$ was as described (Samuels et al., 
198?) 1 inear salt-gradient elution of [A] activity from DEAE-Sephacel was performed by loading $400 \mathrm{ml}$ of phosphocellulose fraction [A] adjusted to $0.15 \mathrm{M} \mathrm{KCl}$ onto a $120 \mathrm{ml}(2.5 \times 24 \mathrm{~cm})$ DEAE-Sephace column. The column was washed with 3 column volumes of Buffer $A$ $+0.1 \mathrm{M} \mathrm{KCl}$. Buffer A consisted of $20 \%$ glycerol, $20 \mathrm{mM}$ HEPES $\mathrm{NaOH}(\mathrm{pH}$ 7.9), $1 \mathrm{mM}$ EDTA, and $1 \mathrm{mM}$ dithiothreitol. The column was eluted with a 6 column volume linear gradient from $0.15 \mathrm{M}-0.4 \mathrm{M} \mathrm{KC}$ in Buffer A. Eleven milliliters fractions were collected, and dialyzed against Buffer $\mathrm{A}+0.1 \mathrm{M} \mathrm{KCl}$.

Linear gradient elution of $[C]$ activity from DNA-cellulose (M Samuels, unpublished data) was performed as follows: $90 \mathrm{ml}$ of frac tion [C] derived from $70 \mathrm{ml}$ of $\mathrm{Hel}$ a WCE, were adjusted to $0.21 \mathrm{M} \mathrm{KC}$ and applied to a $120 \mathrm{ml}(2.5 \times 24 \mathrm{~cm})$ DEAE-Sephacel column equilibrated in Buffer $A+0.1 \mathrm{M} \mathrm{KCl}$ (Samuels et al., 1982). The flow through. which contained $\mathrm{CP} 1, \mathrm{CP} 2$, and NF-1 activities, was applicd to a $40 \mathrm{ml}(2.5 \times 8 \mathrm{~cm})$ DNA-cellulose column equilibrated in Buffer $A+0.1 \mathrm{M} \mathrm{KCl}+5 \mathrm{mM} \mathrm{MgCl}_{2}$. The column was washed with 5 column volumes of equilibration butter and eluted with a 5 column vol ume tinear gradient from $0.1 \mathrm{M}$ to $0.8 \mathrm{M} \mathrm{KCl}$ in Buffer $A+5 \mathrm{mM}$ $\mathrm{MgCl}_{2}$. Ten milliliter fractions were collected and dialyzed against Buffer A + 0.1 M KCl.

Phosphocellulose chromatography of affinity-purified CP1 was carried out on a 50 ॥ phosphocellulose column poured and equilibrated with $A+0.1$ in an Eppendorf $P 1000$ pipet tip plugged with siliconized glass wool. The column was sequentially prewashed with $A+0.1 M$ $\mathrm{KCl}+200 \mu \mathrm{g} / \mathrm{m} \mathrm{BSA}$ and $\mathrm{A}+1.0 \mathrm{M} \mathrm{KCl}$ and equilibrated in $\mathrm{A}+$ $0.06 \mathrm{M} \mathrm{KCl}$. Fifty microliters of affinity-purified $\mathrm{CP} 1$ was loaded onto the column at a flow rate of 6 column volumes per hour. The column was washed with 3 column volumes of $\mathrm{A}+0.06 \mathrm{M} \mathrm{KCl}+200 \mu \mathrm{g} / \mathrm{ml} \mathrm{BSA}$ and eluted with 3 column voiumes of $A+0.6 \mathrm{M} \mathrm{KCl}+200 \mu \mathrm{g} / \mathrm{m} / \mathrm{BSA}$ Twenty-five microliter fractions were collected, and dialyzed against $A$ $+0.1 \mathrm{M} \mathrm{KCl}$

\section{Glycerol Gradient Sedimentation}

Aliquots of fractions $[A B]$ and $[C]$ were dialyzed against $20 \mathrm{mM}$ HEPES $\mathrm{NaOH}(\mathrm{pH} 7.9), 1 \mathrm{mM}$ EDTA, $1 \mathrm{mM}$ DT T, $60 \mathrm{mM} \mathrm{KCl}$, and $8 \%$ glycerol. Fifty microliters of dialyzed fraction [AB] and $50 \mu \mathrm{l}$ of dialyzed fraction [C] were incubated alone or in combination for $10 \mathrm{~min}$ at $30^{\circ} \mathrm{C}$. Reactions were layered onto $10 \%-30 \%$ glycerol gradients and sedimented at $45.000 \mathrm{rpm}$ for $19 \mathrm{hr}$ in a $S W 60$ rotor at $4^{\circ} \mathrm{C}$. Fourteen fractions $(275$ "Il each) were taken from each gradient, and $7 \mu$ of each fraction were tested in a standard CP1 binding assay containing the complementary CP1 fraction and $0.4 \mathrm{ng}$ of the MLP probe. RMC. In a parallel gradient. $50 \mu \mathrm{g}$ each of ovalbumin, bovine serum albumin, carbonic anhydrase, cytochrome $C$, and catalase were sedimented, and portions of cach fraction analyzed by SDS-polyacrylamide gel electrophoresis.

\section{Acknowledgments}

We thank members of the Sharp laboratory for numerous helpful discussions, M. Garcia-Blanco. J. LeBowitz, H. Singh, and S. Hahn for critical reading of the manuscript. S. Scaringe tor synthesizing DNA oligonucleotides. M. Samuels for preparation of some chromatographic fractions, and D. Gaison. N. Speck, M Gilman, J. Morgan, and $G$. Crabtree for some of the plasmids used in this study. We thank $M$. Siafaca for her patience and grace under pressure. L. A. C. is supported by the Harvard Medical School M.D.-Ph.D. program by Public Health Service National Research Service Award 5T 32 GM07753-09 from the National Institute of General Medical Sciences. and by the M.I.T. Department of Biology. A. S. B. is supported by a Leukemia Society Special Fellow Award. This work was supported by U. S. Public Health Service grant PO1-CA42063 from the National Institutes of

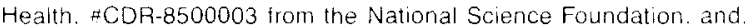
partially, by National Cancer Institute Cancer Center core grant P30 CA14051 to P. A. S

The costs of publication of this article were defrayed in part by the payment of page charges. This article must therefore be nereby marked "advertisement" in accordance with 18 U.S.C. Section 1734 solely to indicate this fact

Received February 2. 1988; revised February 18. 1988

\section{References}

Arriza. J. L., Weinberger, C., Cerelli, G, Glaser, T. M.. Handelin. B. L Housman, D. E., and Evans, R. M. (1987). Cloning of the human miner. alocorticoid receptor complementary DNA: structurat and functionat kinstip with the glucocorticoid receptor. Science 237, 268-274.

Baldwin, A. S., and Sharp, P. A. (1987). Binding of a nuclear factor to a regulatory sequence in the promoter of the mouse H.2K class I ma jor histocompatibility gene. Mol. Cell. Biol. 7, 305-313.

Barberis, A., Superti-Furga, G., and Busslinger, M. (1987). Mutually exclusive interaction of the CCAAT-binding factor and of a displacement protein with overlapping sequences of a histone gene promoter Coll $50,347-359$

Benois1, C., OHare. K., Breathnach. R., and Chambon. P. (1980). The ovalbumin gene. sequence of putative control regions. Nuct. Acids Res. 8, 127-142.

Carthew. R. W. Chodosh, L. A . and Sharp, P. A. (1985). An RNA poly. merase II transcription factor binds to an upstream element in the adenovirus major late promoter. Cell 43, 439-448.

Charnay. P., Mellon, P., and Maniatis, T. (1985). Linker scanring mutagenesis of the $5^{\prime}$-flanking region of the mouse $\beta$-major-globin gene: sequence requirements for transcription in erythroid and nonerythroid cells. Mol. Cell Biol. 5, 1498-1511

Chodosh, L. A., Carthew, R. W. and Sharp, P. A. (1986). A single polypeptide possesses the binding and transcription activities of the adenovirus major late transcription factor. Mol. Cell. Biol 6, 4723-4733 Chodosh, L. A., Carthew, R. W. Morgan, J. G.. Crabtree, G. R. and Sharp. H. A. (1987). The adenovirus major late transcription factor activates the rat $\gamma$-fibrinogen promoter Science 238, 684-688.

Chodosh, L. A. Olesen. J.. Hahn, S., Baldwin, A. S.. Guarente. L.. and Sharp, P. A. (1988). A yeast and a human CCAAT-binding protein have heterologous subunits that are functionaliy interchangeable. Cell 53. 25-35

Cohen, R. B., Sheffery, M., and Kim, C. G. (1986). Partial purification of a nuclear protein that binds to the CCAAT box of the mouse $u_{1}$-globin gene. Mol. Cell Biol. 6, 821-832.

De Vries, E., Van Driel, W. Van den Heuvel. S. J.. and Van der Vliet. P. C. (1987). Contactpoint analysis of the HeLa nuclear factor I recogni tion site reveals symmetrical binding at one side of the DNA helix. EMBO J. 6, 161-168

Dorn, A., Bollekens, J., Staub, A., Benoist, C., and Mathis, D. (1987). A multiplicity of CCAAT box-binding proteins. Cell 50, 863-872

Efstratiadis, A., Posakony, J. W., Maniatis. T., Lawn, R. M., O'Connell. C., Spritz, R. A., DeRiel, J. K., Forget, B. G., Weissmann, S. M.. Slightom, J. L., Blechl, A. E., Smithies, O., Baralle, F E. Shoulders. C. C., and Proudfout, N. J. (1980). The struclure and evolution of the human $\beta$-globin gene family. Cell 21, 653-668.

Fire, A., Baker. C. C., Manley, J. L., Ziff, E. B.. and Sharp. P. A. (1981). In vitro transcription of adenovirus. J. Virol. 40,703-719.

Fried, M., and Crothers, D. M. (1981). Equilibria and kinetics of lac repressor-operator interactions by polyacrylamide get electrophoresis. Nucl. Acids Res. 9, 6505-6525.

Galson, D., and Housman, D. E. (1988). Detection of two tissue-specific DNA-binding proteins with affinity for sites in the mouse (;-globin inter. vening sequence 2. Mol. Cell. Biol. 8, 381-392.

Garner, M. M., and Revzin, A. (1981). A gel electrophoresis method for quantifying the binding of proteins to specific DNA regions. Applica. tions to components of the $E$. coli lactose operon regulatory system. Nucl. Acids hes. 9. 3047-3060.

Graves, B. J. Johnson. P. F. and MCKnight. S. L. (1986). Homologous recognition of a promoter domain common to the MSV LTR and the HSV tk gene. Cell 44, 565-576

Green, S. Walter, P., Kumar, V., Krust, A., Bornert. J.-M., Argos. P., and Chambon, P. (1986). Human estrogen receptor cDNA: sequence, expression and homology to v-erb-A. Nature 320, 134-139.

Guarente, L.. Lalonde, B., Gifford, P.. and Alani, E. (1984). Distinctly regulated iandem upstream activation sites mediate catabolite repression of the CYC1 gene of S. cerevisiae. Cell 36. 503-511. 
Hahn, S. and Guarente, L. (1988). Yeast HAP2 and HAP3: transcriptional activators in a complex. Science, in press.

Hahn, S., Pinkham, J., Wei, R., Miller, R., and Guarente, L. (1988). The HAH'3 regulatory locus of Saccharomyces cerevisiae encodes divergent overlapping transcripts. Mol. Cell. Biol. 8, 655-663.

Hatamochi, A., Paterson, B, and de Crombrugghe, B. (1986). Differential binding of a CCAAT DNA binding factor to the promoters of the mouse $\alpha 2(\mid)$ and $\alpha 1(I I)$ collagen genes. J. Biol. Chem. 261, 1131011314.

Hollenberg, S. M., Weinberger, C., Ong, E. S., Cerelli, G., Oro, A Lebo, R., Thompson, E. B., Rosenfeld, M. G., and Evans, R. M. (1985). Primary structure and expression of a functional human glucocorticoid receptor cDNA. Nature 318, 635-641.

Jones, K. A., Yamamoto, K. R., and Tjian. R. (1985). Two distinct transcription factors bind to the HSV thymidine kinase promoter in vitro. Cell 42, 559-572.

Jones, K. A., Kadonaga, J. T., Rosenfeld, P. J., Kelly, T. J., and Tjian, R. (1987). A cellular DNA-binding protein that activates eukaryotic transcription and DNA replication Cell 48, 79-89

Kingston, R. E., Baldwin, A. S., and Sharp, P. A. (1985). Transcription control by oncogenes. Cell $41,3-5$.

Klock, G., Strahle, U., and Schutz, G. (1987). Estrogen and glucocorticoid responsive elements are closely related but distinct. Nature 329 , 734-736.

Knight, G. B., Gudas, J. M., and Pardee, A. B. (1987). Cell-cycle-specific interaction of nuclear DNA-binding proteins with a CCAAT sequence from the human thymidine kinase gene. Proc. Natl. Acad. Sci. USA 84 , $8350-8354$

Leegwater, P. A., Van Driel, W., and Van der Vliet, P. C. (1985). Recognition site of nuclear factor I, a sequence-specific DNA-binding protein from HeLa cells that stimulates adenovirus DNA replication. EMBO J. 1. 1515-1521.

Leegwater, P. A., Van der Vliet, P. C., Rupp, R. A., Nowock, J., and Sippel, A. E. (1986). Functional homology between the sequence-specific DNA-binding proteins nuclear factor I from HeLa cells and the TGGCA protein from chicken liver. EMBO J. 5, 381-386.

Loosfelt, H., Atger, M., Misrahi, M., Guiochon-Mantel, A., Meriel, C., Logeat, F., Benarous, R., and Milgrom, E. (1986). Cloning and sequence analysis of rabbit progesterone-receptor complementary DNA. Proc. Natl. Acad. Sci. USA 83, 9045-9049.

Maniatis, T., Fritsch, E. F., and Sambrook, J. (1982). Molecular Cloning. A Laboratory Manual. (Cold Spring Harbor, New York: Cold Spring Harbor Laboratory).

Maniatis, T., Goodbourn, S., and Fischer, J. A. (1987). Regulation of inducible and tissue-specific gene expression. Science 236, 1237-1244.

Manley, J. L., Fire, A., Cano, A., Sharp, P. A., and Gefter, M. L. (1980). DNA-dependent transcription of adenovirus genes in a soluble wholecell extract. Proc. Natl. Acad. Sci. USA 77, 3855-3859.

Maxam, A., and Gilbert, W. (1980). Sequencing end-labeled DNA with base-specific chemical cleavages. Meth. Enzymol. 65, 499-560.

McDonnell, D. P., Mangelsdorf, D. J., Pike, J. W., Haussler, M. R., and O'Malley, B. W. (1987). Molecular cloning of complementary DNA encoding the avian receptor for vitamin D. Science 235, 1214-1217.

McKnight, S., and Tjian, R. (1986). Transcriptional selectivity of viral genes in mammalian cells. Cell 46, 795805

Mellon, P., Parker, V., Gluzman, Y., and Maniatis, T. (1981). Identification of DNA sequences required for transcription of the human a 1 globin gene in a new SV-40 host-vector system. Cell 27, 279-288.

Miksicek, R., Borgmeyer, U., and Nowock, J. (1987). Interaction of the TGGCA-binding protein with upstream sequences is required for efficient transcription of mouse mammary tumor virus. EMBO J. 6 . 1355-1360.

Morgan, W. D., Williams, G. T., Morimoto, R. I. Greene, J., Kingston, R. E., and Tjian, R. (1987). Two transcriptional activators, CCAAT-boxbinding transcription factor and heat shock transcription factor, interact with a human hsp70 gene promoter. Mol. Cell Biol. 7, 1129-1138.

Morgan, J. G., Courtois, G., Fourel, G. . Chodosh, L. A., Campbell, L., Evans, E., and Crabtree, G. R. (1988). SP1, a CAAT-binding factor and the adenovirus major late promoter transcription factor interact with functional regions of the $\gamma$-fibrinogen promoter. Mol. Cell Biol., in press. Myers, R. M., Tilly, K., and Maniatis, T. (1986). Fine structure genetic analysis of a $\beta$-globin promoter. Science 232, 613-618.

Nagata, K., Guggenheimer, R. A., and Hurwitz, J. (1983). Specific binding of a cellular DNA replication protein to the origin of replication of adenovirus DNA. Proc. Natl. Acad. Sci. USA 80, 6177-6181.

Oikarinen, J., Hatamochi, A., and de Crombrugghe, B. (1987). Separate binding sites for nuclear factor 1 and a CCAAT DNA binding factor in the mouse $\alpha_{2}(I)$ collagen promoter. J. Biol. Chem. 262, 1106411070.

Olesen, J., Hahn, S., and Guarente, L. (1987). Yeast HAP2 and HAP3 activators both bind to the $\mathrm{CYC} 1$ upstream activation site, UAS2, in an interdependent manner. Cell 51, 953961.

Petkovich, M., Brand, N. J., Krust, A., and Chambon, P. (1987). A human retinoic acid receptor which belongs to the family of nuclear receptors. Nature $330,444-450$.

Pinkham, J. L., and Guarente, L. (1985). Cloning and molecular analysis of the HAP2 locus: a global regulator of respiratory genes in $\mathrm{S}$. cerevisiae. Mol. Cell. Biol. 5, 3410-3416.

Rosenfeld, P. J., and Kelly, T. J. (1986). Purification of nuclear factor I by DNA recognition site affinity chromatography. J. Biol. Chem. 261, 1398-1408.

Rosenfeld, P. J., O'Neill, E. A., Wides, R. J., and Kelly, T. J. (1987). Sequence-specific interactions between cellular DNA-binding proteins and the adenovirus origin of DNA replication. Mol. Cell. Biol. 7, 875-886.

Samuels, M. Fire, A., and Sharp, P. A. (1982). Separation and characterization of factors mediating accurate transcription by RNA polymerase II. J. Biol. Chem. 257, 14419-14427.

Siebenlist, U., Simpson, R. B., and Gilbert, W. (1980). E. coli RNA polymerase interacts homologously with two different promoters. Cell 20 , 269-281.

Singh, H., Sen, R., Baltimore, D., and Sharp, P. A. (1986). A nuclear factor that binds to a conserved sequence motif in transcriptional control elements of immunoglobulin genes. Nature 319, 154-158.

Strahle, U., Klock, G., and Schutz, G. (1987). A DNA sequence of 15 base pairs is sufficient to mediate both glucocorticoid and progesterone induction of gene expression. Proc. Natl. Acad. Sci. USA 84 , 1871-7875.

Tsai, S. Y., Sagami, I., Wang, H., Tsai, M. J., and O'Malley, B. W. (1987) Interactions between a DNA-binding transcription factor (COUP) and a non-DNA binding factor ( $\$ 300-11)$. Cell 50, 701-709.

Von der Ahe, D., Renoir, J.-M., Buchou, T., Baulieu, E.-E., and Beato, M. (1986). Receptors for glucocorticosteroid and progesterone recognize distinct features of a DNA regulatory element. Proc. Natl. Acad. Sci. USA 83, 2817-2721

Weinberger, C., Hollenberg, S. M., Rosenteld, M. G., and Evans, R. M (1985). Domain structure of human glucocorticoid receptor and its relationship to the v-erb-A oncogene product. Nature 318, 670-672.

Weinberger, C., Thompson, C. C., Ong, E. S., Lebo, R., Gruol, D. J. and Evans, R. M. (1986). The c-erb-A gene encodes a thyroid hormone receptor. Nature $324,641-646$

Wu, B. J., Williams, G. T., and Morimoto, R. I. (1987). Detection of three protein binding sites in the serum-regulated promoter of the human gene encoding the 70-kDa heat shock protein. Proc. Natl. Acad. Sci. USA 84, 2203-2207.

Yamamoto, K. R. (1985). Steroid receptor regulated transcription of specific genes and gene networks. Annu. Rev. Genet. 19, 209-252. 